Old Dominion University

ODU Digital Commons

Winter 2018

\title{
Factors Influencing Student Enrollment in Career Academy Programs
}

Whitney Stokes Ketchledge

Old Dominion University, wstok001@odu.edu

Follow this and additional works at: https://digitalcommons.odu.edu/stemps_etds

Part of the Secondary Education Commons, and the Vocational Education Commons

\section{Recommended Citation}

Ketchledge, Whitney S.. "Factors Influencing Student Enrollment in Career Academy Programs" (2018). Doctor of Philosophy (PhD), Dissertation, STEM Education \& Professional Studies, Old Dominion University, DOI: 10.25777/jbk6-eh25

https://digitalcommons.odu.edu/stemps_etds/43

This Dissertation is brought to you for free and open access by the STEM Education \& Professional Studies at ODU Digital Commons. It has been accepted for inclusion in STEMPS Theses \& Dissertations by an authorized administrator of ODU Digital Commons. For more information, please contact digitalcommons@odu.edu. 


\title{
FACTORS INFLUENCING STUDENT ENROLLMENT IN CAREER ACADEMY PROGRAMS
}

\author{
by \\ Whitney Stokes Ketchledge \\ B.S. May 2006, Old Dominion University \\ M.S. July 2011, Virginia Polytechnic Institute and State University \\ Ed.S. August 2014, Old Dominion University \\ A Dissertation Submitted to the Faculty of \\ Old Dominion University in Partial Fulfillment of the \\ Requirements for the Degree of \\ DOCTOR OF PHILOSOPHY IN EDUCATION \\ OCCUPATIONAL AND TECHNICAL STUDIES \\ OLD DOMINION UNIVERSITY \\ December 2018
}

Approved by:

Michael Kosloski (Director)

Philip A. Reed (Member)

Karen Sanzo (Member) 


\author{
ABSTRACT \\ FACTORS INFLUENCING STUDENT ENROLLMENT IN \\ CAREER ACADEMY PROGRAMS \\ Whitney Stokes Ketchledge \\ Old Dominion University, 2018 \\ Director: Dr. Michael Kosloski
}

Career academies are small learning communities that allow high school students to learn their core content in the context of the career field they may be interested in pursuing. This type of learning environment incorporates business and industry and postsecondary institutions so academy students receive academic curricula that prepares them for higher education and allows students to have experiences in the career field. There is considerable research demonstrating strong benefits of the academy model to students and teachers, but there is little indicating why students enroll in the academy and what methods of recruitment may work best.

The purpose of this study was to assess factors influencing students' decisions to enroll in career academy programs. The study investigated two research questions. The first research question looked at factors that influence students to apply for academy programs. The second research question explored reasons students have for choosing not to enroll in academy programs.

A survey conducted by the school division was used to collect the necessary data with $n=401$ responses from students enrolled in an academy and $n=2,421$ responses from students not enrolled in an academy. To investigate factors influencing students to apply for academy programs, a factor analysis was performed. This analysis resulted in two larger groupings linking items together based on program experience and student 
attitudes. A Pareto analysis indicated that counselors were the greatest influencing factors on student decisions to enroll in career academy programs. Parents, teachers, other students, the course catalog, website, and brochure also played a considerable role in how students learned about the academies. To investigate reasons students have for not applying, a Pareto analysis was conducted with the reasons of not knowing, not interested, and missed deadline as most influential. 
Copyright, 2018, by Whitney Stokes Ketchledge, All Rights Reserved. 
This dissertation is dedicated to my children, Izabel and Tanner. May you always work hard to achieve your goals and continue to be learners throughout your lives. To my husband Noah, thank you for pushing me and always believing in me. I couldn't have done this without you! 


\section{ACKNOWLEDGMENTS}

There are so many people to thank for their time and efforts in helping me through this journey. To my committee director, Dr. Mickey Kosloski, thank you for not giving up on me and for pushing me to do my best. You have had such an impact on my life in many different ways and I hope we continue to connect and work together moving forward. To Dr. Reed and Dr. Sanzo, thank you for your time and contributions throughout this process. You have each contributed to my education over multiple degrees and taught me more than I can put onto paper. To Dr. Pribesh, you told us we had to have some perseverance and while you probably did not know how long I would need to preserver, your advice stuck with me all the way through. You made a huge impact on me and I am so grateful for all that you taught me. Dr. Cooper, I would have been lost without you and I think there are many others who feel this way as well. Your contributions to so many efforts and in so many different lives will never be forgotten. Thank you for all of your time, efforts, and encouragement, and best wishes for a wonderful retirement.

To all of my amazing cohort friends and mentors, thank you for always being willing to take the phone calls, respond to emails, read drafts, and provide advice. We were told we would make friendships that would last the rest of our lives and that is exactly what you have turned out to be for me. I look forward to continuing our connections even though we are now spread out all over the United States.

Finally, thank you to some of my closest friends and family. So many of you called me frequently to make sure I was getting the work done and staying on track. Many times I found the reminders annoying, but who knows where I would be without them. This would not have been completed without each of you and I am forever grateful! 
TABLE OF CONTENTS

LIST OF TABLES..................................................................................................................................................................................viii

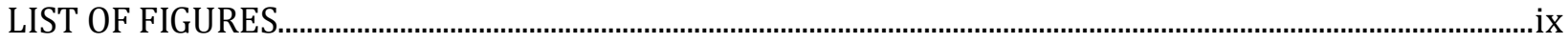

I. INTRODUCTION

BACKGROUND AND SIGNIFICANCE................................................................................................................

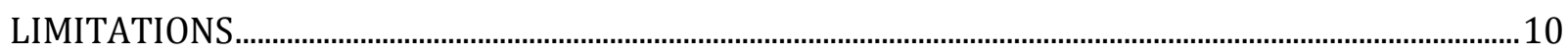

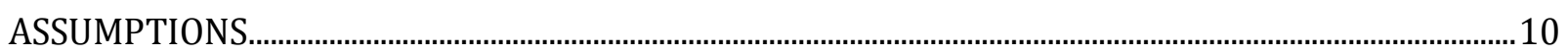

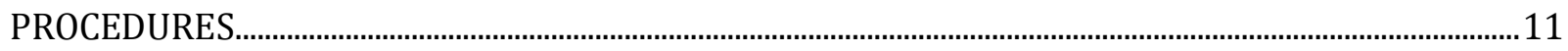

DEFINITIONS OF TERMS ..............................................................................................................................................12

SUMMARY AND OVERVIEW ..........................................................................................................................................14

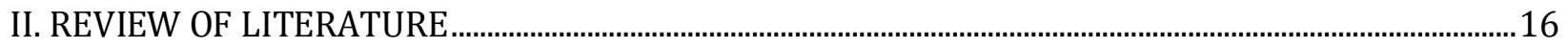

CAREER AND TECHNICAL EDUCATION …………………………………................................................................16

HISTORY OF CAREER AND TECHNICAL EDUCATION ............................................................................16

CAREER AND TECHNICAL EDUCATION LEGISLATION …………………….............................................18

CAREER AND TECHNICAL EDUCATION STUDENT ORGANIZATIONS.................................................20

INTEGRATION OF ACADEMIC CONTENT ........................................................................................................22

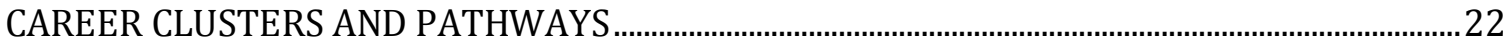

RESEARCH IN CAREER AND TECHNICAL EDUCATION ………………………………………………23

PROJECTIONS FOR CAREER AND TECHNICAL EDUCATION...............................................................26

CAREER CLUSTERS, PATHWAYS, AND PROGRAMS OF STUDY......................................................................2

EUROPEAN MODEL ………………………........................................................................................................................

CAREER ACADEMY CONCEPT ............................................................................................................................

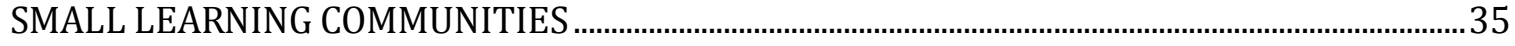

COLLEGE PREPARATORY CURRICULUM WITH A CAREER THEME ………….....................................36

PARTNERSHIPS WITH EMPLOYERS..............................................................................................................36

HISTORY AND DEVELOPMENT OF CAREER ACADEMIES.....................................................................

RESEARCH FINDINGS ON CAREER ACADEMY PROGRAMS................................................................... 38

CAREER INTEREST INVENTORIES............................................................................................................................. 40

FACTORS INLUENCING HIGH SCHOOL STUDENTS .............................................................................................4

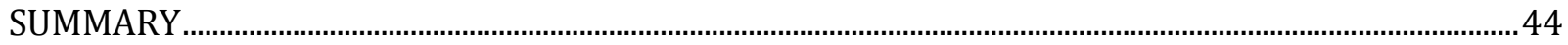




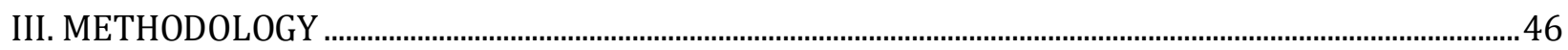

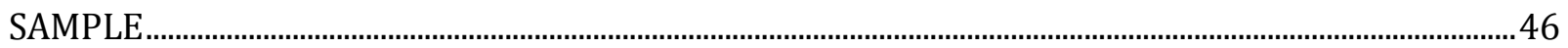

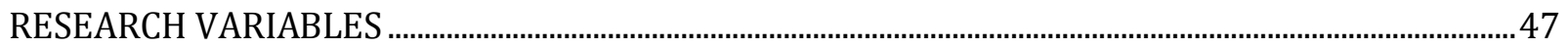

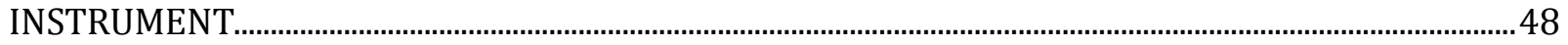

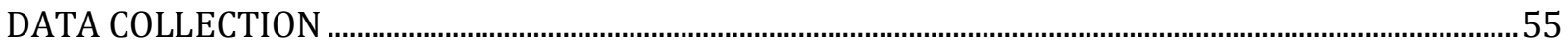

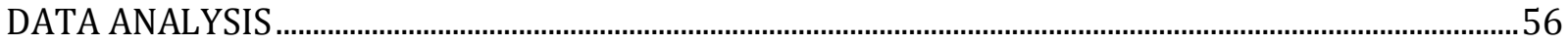

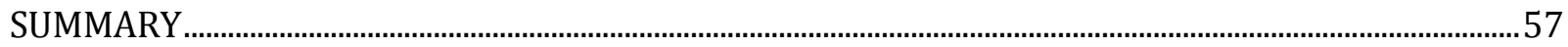

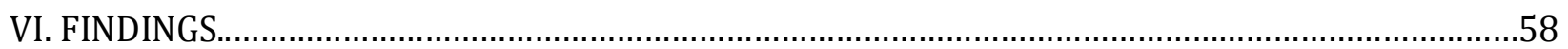

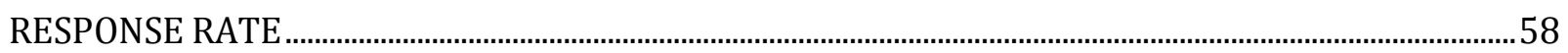

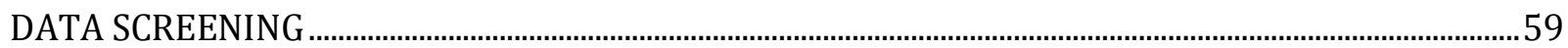

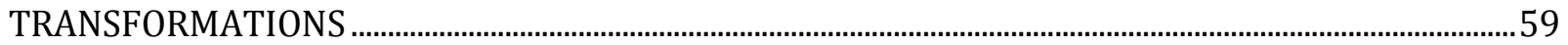

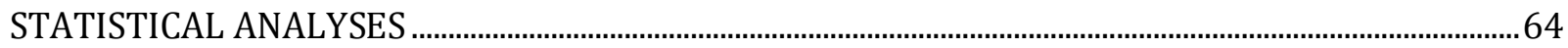

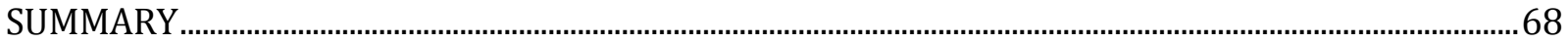

V. SUMMARY, CONCLUSIONS, AND RECOMMENDATIONS .......................................................... 70

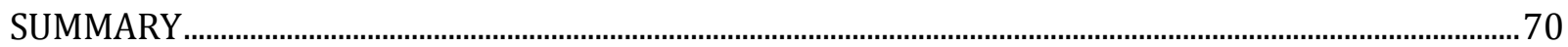

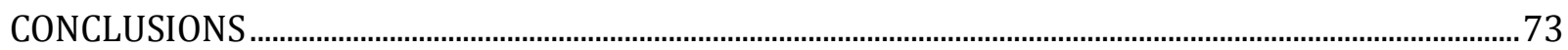

RECOMMENDATIONS.......................................................................................................................................

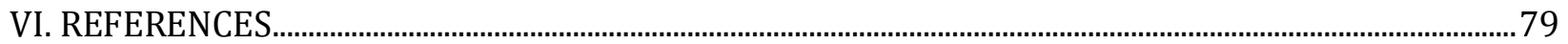

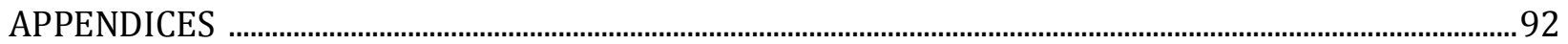

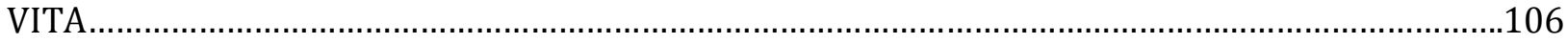




\section{LIST OF TABLES}

Table

1. GROWTH OF THREE CAREER ACADEMY NETWORKS ……..............................................................38

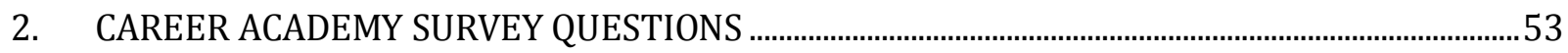

3. IMPORTANCE ACADEMY STUDENTS GIVE FOR BEST FEATURES OF AND REASONS THEY

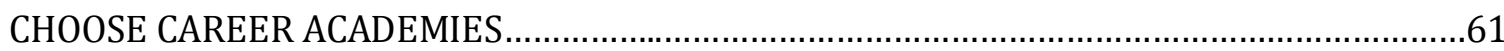

4. FACTORS ACADEMY STUDENTS SELECTED FOR HOW THEY LEARNED ABOUT CAREER

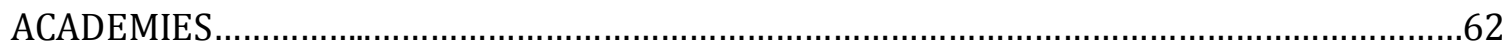

5. REASONS WHY NON ACADEMY STUDENTS DO NOT ATTEND CAREER ACADEMY...............63

6. DATA ADEQUACY AND GOODNESS-OF-FIT OF ACADEMY EFA MODEL USING QUESTIONS 9 AND 10 DATA 


\section{LIST OF FIGURES}

Figure

Page

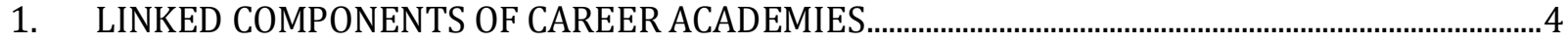

2. PATH DIAGRAM REPRESENTING BEST FIT TWO FACTOR MODEL USING TOP SIX ITEMS

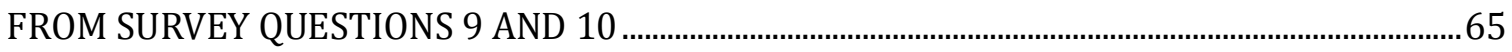

3. PARETO ANALYSIS, ACADEMY INFLUENCE FACTORS.....................................................................66

4. PARETO ANALYSIS, REASONS FOR NOT APPLYING .....................................................................6 


\section{CHAPTER I}

\section{INTRODUCTION}

Education reform in the United States has been a recurring theme for decades. The need to strengthen our economy is great, and a strong educational system is required to create a skilled, adaptive, and creative workforce in the United States. It is critical that schools prepare all students for their future careers in order to secure a brighter future for our country (Brand, Valent, \& Browning, 2013). A difficulty for school systems can be keeping up with the rapid pace of our changing society. Many programs have been implemented in school systems and then quickly disappear, but few of these programs have offered the reform needed to prepare students for postsecondary education and/or the workforce (Hyslop, 2009). In career and technical education, reform has been initiated with every reauthorization of the Carl D. Perkins federal legislation (Schwartz, 2016).

According to the most recent authorization of the Carl D. Perkins Career and Technical Education Improvement Act (2006), career and technical education provides:

...organized educational activities that offer a sequence of courses that provides individuals with coherent and rigorous content aligned with challenging academic standards and relevant technical knowledge and skills needed to prepare for further education and careers in current or emerging professions. It includes competency-based applied learning that contributes to the academic knowledge, higher-order reasoning and

problem-solving skills, work attitudes, general employability skills, technical skills, and occupation-specific skills, and knowledge of all aspects of an industry, including entrepreneurship, of an individual (S.250-4). 
The Carl D. Perkins Career and Technical Education Improvement Act of 2006 was developed to "integrate rigorous and challenging academic and career and technical instruction" (S. 250-2). Academic subject areas are taught and reinforced within career and technical education courses, which allow students to see how they will use these concepts in a career field (Carl D. Perkins Career and Technical Education Improvement Act, 2006).

Integrating academic subject areas with career and technical education knowledge can help to close the gap for students "who are not able to make the connection between their educational achievement and a future high-wage, high-demand, and satisfying career" (Loera, Nakamoto, Oh, \& Rueda, 2013, p. 173). A stronger emphasis on bringing career and technical education into core content area classrooms and bringing core content into career and technical education classes allows academic knowledge to be taught in the context of the career field the student is interested in studying, therefore making the content more meaningful. Adding context to content can provide a more meaningful educational experience due to increased support, and it can also have a positive impact on student engagement (Kuo, 2010). This can aid school divisions in preparing students for college, careers, and life (Stern, 2015).

The integration of academic content with career and technical content is essential because “neither CTE nor traditional academic coursework alone can deliver" the outcomes today's economy depends on (Hoachlander \& Steinhauser, 2015, para. 5). Integrating academic subject areas with career and technical education can be done through small learning communities with specialized curricula (Loera, et al., 2013). One method for this integration is through the career academy model. This small learning community model combines career and technical education and academic content with the intention of preparing students for college and careers (College and Career Academy Support Network, 2012). 
Although career academy concepts can be traced back to the 1700s, in their present form career academies began in 1969 in Philadelphia, and they continued their early development into the 1980s when the National Academy Foundation was formed (Stern, 2015). The National Academy Foundation currently supports academies in 38 states, including the 300 California Partnership Academies (Stern, 2015). By 2010 there were approximately 7,000 career academies in the United States (Stern, Dayton, \& Raby, 2010).

According to the College and Career Academy Support Network, "A career academy is a type of school-within-a-school or small learning community that provides a college-preparatory curriculum with a career-related theme" (Stern et al., 2010, p. 4). A career academy combines a traditional academic education with career and technical education, allowing students to focus their high school education on a particular Career Pathway. Figure 1 illustrates three themes of a career academy model, as identified by The Career Academy Support Network. These include:

1. It is a small learning community composed of students who have classes together and a group of teachers that work together to develop the program of study for the academy students.

2. The academy combines academic curricula that prepare a student for postsecondary education and a career theme that the student is interested in pursuing. This career theme is interwoven into the students' core subject classes through readings, assignments, and projects.

3. The career academy has close relationships with employers and postsecondary educational institutions in order to develop an advisory group and provide internship, mentorship, articulation agreements, and other opportunities for the academy students to receive direct experience in their chosen field of study (Stern et al., 2010). 


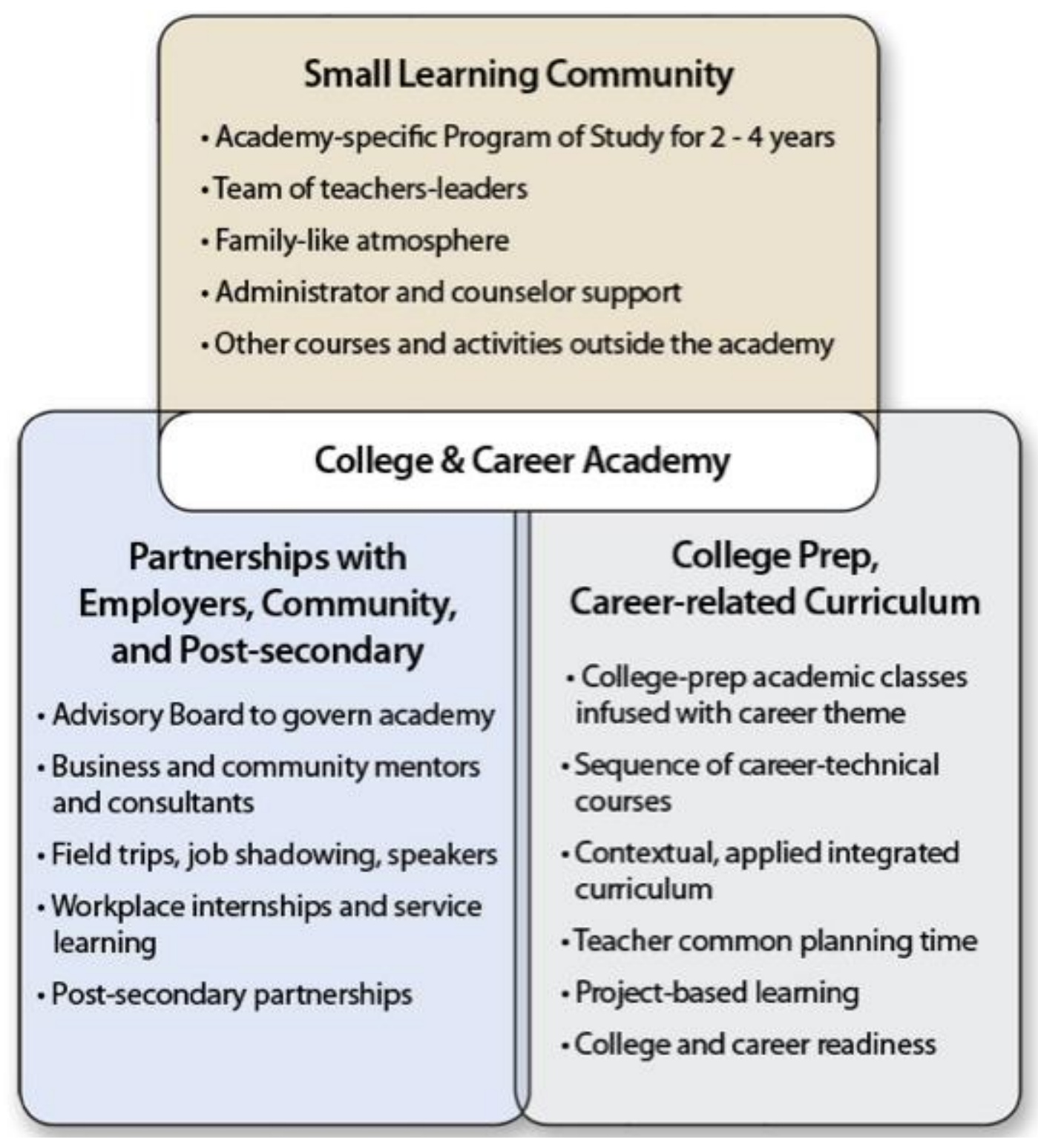

Figure 1. Linked Components of College \& Career Academies. From "College and career academies: An overview,” by College and Career Academy Support Network, 2012.

Career academy programs offer small learning communities incorporating a culture that enables students to interact and enhance their academic achievement, as well as connecting educational experiences with potential post-secondary and career opportunities (Loera, et al., 2013). The career academy model gives educators a way to continue to meet requirements set forth by the Carl D. Perkins Career and Technical Education Improvement Act of 2006 by requiring career and technical education and core content teachers to work together so the 
student can see how the content they are learning will be used in a variety of Career Pathways. Furthermore, it provides the means for reform in secondary education by creating interdisciplinary connections for students and providing students with opportunities to receive work-based learning experiences.

More often than not, parents and teachers alike struggle to help children determine their career paths and make career decisions. Many parents and teachers then want to know how a student is supposed to decide what career they are interested in pursuing as early as middle school. In many academy models, students apply to enter an academy when they are in eighth or ninth grade and the students participate in the academy from grades nine/ten through twelve. However, the question remains, do students have the knowledge and understanding to determine what career path they want to follow when they are only 13 or 14 years old? Little research has been conducted to determine what influences students to apply to and participate in a career academy program, and whether they subsequently pursue the academy career field after they complete high school. Therefore, understanding the factors that influence students to enroll in the career academy program can be helpful in program design, recruitment, retention of students, and in assisting the students with their post-secondary plans.

\section{Purpose Statement}

The purpose of this study was to assess factors influencing students' decisions to enroll in career academy programs.

\section{Research Questions}

The research questions addressed in this study were as follows:

$\mathrm{RQ}_{1}$ : What factors influence students to apply for career academy programs?

$\mathrm{RQ}_{2}$ : What reasons do students have for choosing not to enroll in a career academy? 


\section{Background and Significance}

The global economy is continuously changing, and with these changes the "economy demands a better educated workforce,” (Brand et al., 2013, p. 1). The national school-to-work movement and the School-to-Work Opportunities Act of 1994 proposed several different approaches to better prepare high school students for the future. The goal of the 1994 Act was to provide funds for schools to make education relevant to the future world of work (School-toWork Opportunities Act, 1994). The goals of this Act were to "integrate academic and vocational education, link secondary and postsecondary education, provide learning opportunities at the work site, and fully engage the private sector in the process" (p. 1). Schools were required to provide school-based learning, work-based learning, and connecting activities to help students learn the skills that are valued in the workplace. Teaching students the skills they need to be able to find mid- to high-level trade, technical, and professional positions is a required part of building a strong economy to compete in the global economy (Stone, 2014).

Work-based learning has come in many forms including "cooperative education, mentoring, job shadowing, school-based enterprises, and career academies" (Rojewski, et al., 2010, p. 3). Cooperative education allows students to receive high school credit for part-time employment. Students are supervised by their teacher/coordinator and the work experience allows for the application of those skills and knowledge that are learned in the classroom. Mentoring and job shadowing opportunities allow students to see what it would be like to work in a particular career by spending time with someone working in that area and participating in elements of their workplace. School-based enterprises are businesses operated within the school environment by the students under the supervision of a school sponsor. All of these programs were designed to put education in a controlled work-based environment (Rojewski, et al., 2010). 
Career academies often integrate work-based learning through cooperative education, mentoring, internships, and apprenticeships. According to Orr (2005), career academies are able to combine preparation for college and a career with unique learning experiences both in and out of the classroom to better prepare students for the future. While the main goal of a career academy program is to prepare students for college and/or the workplace, the academies also provide "more supportive teaching and learning communities within high schools" (Kemple, 1997, p. 1). Some students will follow their program of study into college or a training program, while other students will choose to progress into the workplace. Students are prepared for college and a career regardless of the path they choose to take after high school. The ultimate outcome is to help students focus their learning on the area of study that they are interested and help them to explore a career field they believe they might pursue (Smith, 2008).

The College and Career Academy Support Network (CCASN) has identified three career academy networks with over 1,000 state-funded academies throughout the United States. The three recognized academy networks are Philadelphia, California, and National Academy Foundation. In total, there are approximately 7,000 high schools across the United States with at least one academy in operation (Stern et al., 2010). The current career academy model began with the intention of improving dropout rates and preparing students for future careers. This idea began to spread and eventually academies added preparation for postsecondary education in addition to career preparation (Stern et al., 2010). Academy themes cover a variety of fields including "business, automotive, health, environmental technology, law, horticulture, tourism, aviation" (p. 6) and many more Career Pathways. Schools are encouraged to develop academies focusing on career fields prominent in the local economy for potential business and industry partners and have a positive outlook for job placement (Stone, 2014). 
Research has shown that there are many positive effects on student achievement from participation in a career academy program, but there has been no research on factors influencing student selection of the programs. Positive outcomes include increased graduation rates, improved attendance, improved school climate, and higher sustained earning after graduation (Kemple \& Scott-Clayton, 2004; Kemple \& Snipes, 2000; Kemple \& Wilbur, 2008; Stern et al., 2010). Kemple's 1997 study for the Manpower Demonstration Research Corporation found “career academies provide their students and teachers with a greater degree of institutional and interpersonal support than is available to their non-academy counterparts in the same comprehensive high schools" (p. 1). Students from this study reported that their "schoolwork seems more relevant to their future education and career goals" (Kemple, 1997, p. 1).

Kemple and Scott-Clayton (2004) and Maxwell (2001) also found career academy students had increased wages, more work hours, and more stability than other graduates after one year of graduating from the career academy. This was especially evident for male academy graduates who had been considered at-risk of dropping out. Kuo (2010) found the opportunities for career and college experiences provided in career academy programs have positive impacts on career achievements. Career academies have also been found to increase connections between students and faculty (Dixon, Cotner, Wilson, \& Borman, 2011), allow students to find more relevance in their education (Davis \& McPartland, 2012), and improve the skills needed for students to be successful in a career in the current and future economy (Stone \& Lewis, 2012). However, factors for enrolling in career academy programs, that could be helpful in the design, recruitment, and retention of students for these programs, have not been researched.

The 2006 reauthorization of the Carl D. Perkins Career and Technical Education Improvement Act continued to focus on increasing efforts to combine core academic subjects 
with career and technical education, strengthen the focus on responding to the needs of the economy, and provide career guidance to students. This means designing new ways to teach core academic subjects within career and technical education courses and providing documentation of the integration (Threeton, 2007). MGT of America, Inc. (2009) completed an efficiency study of an urban school division in the mid-atlantic region in an effort to help the school division reduce costs and increase effectiveness. Among their findings was the recommendation to implement high school career academies and implement career planning programs into school guidance departments to create academic and career plans for all students. The career academy model is one of the many ways to blend academic and work-based learning strategies, and this school division began making plans to implement these programs throughout the district (MGT of America, 2009).

In order to begin the transformation process, the school division (2009) identified the available courses and current faculty of the career and technical education programs at each of the high schools to determine which Career Pathways would be the best fit to begin the academies at each particular school. Committees were formed in the district composed of administrators, teachers, parents, students, postsecondary representatives, and members of local business and industry. Each of the high schools began working on planning and implementing the programs that were recommended. School-based academy teams participated in professional development to help them understand the career academy concept before implementation. Many questions were raised as to why students would enroll in these programs and if the students could actually identify their career goals before attending high school.

Students applied to the career academy program of their choice when they were in eighth grade. Determining the factors influencing students to apply to a particular career academy 
program as opposed to enrolling in their zoned high school comprehensive program can have a positive impact on career academy recruitment efforts and program development. Determining these influential factors may also influence individual career development plans as well as mentorship and capstone opportunities later in the career academy program by ensuring students are enrolled in programs related to their career interest areas. Knowledge of student interest is crucial to further development of career academy programs that fit the needs of all students.

\section{Limitations}

This study took place in an urban school division using all comprehensive public high schools within that school division. The school division conducted the survey, collected the data, and the research questions were answered using the existing data from the school division. Information from the survey instrument was self-reported by the students and participation in the survey was voluntary. The study is limited to analyzing the factors influencing the students' decision to enroll in the career academy program. The study is limited to the comprehensive high schools in a public school division in the mid-Atlantic region. Findings of this study may or may not be generalizable to other school divisions. Existing career academy programs are at various stages of implementation with one academy being established and one academy just beginning. Students enrolled in each career academy program have a varying knowledge base of the career academy program. The study is also limited by not utilizing all Career Clusters.

\section{Assumptions}

The following assumptions were held constant in this study:

- All rising ninth grade students in the school division were given the opportunity to apply for one of the career academy programs. 
- Students admitted to the career academy program were selected based on their career interests, application, disciplinary history, and attendance records.

- The study uses existing data collected by the participating school division and assumes proper data collection protocols were followed.

\section{Procedures}

This was a quantitative study of students within an urban school division in the midAtlantic region to determine the factors influencing students' decision to enroll or not enroll in the career academy programs. The subjects for this study were high school students in the comprehensive high schools. Information about each academy was sent home to every eighth grade student during the fall of his or her eighth grade year. Parent nights were held at each high school academy program and parents of rising ninth grade students were invited to meet the academy team and learn more about the program. A page on the school division website was developed for each career academy, career academy information was placed in the division course catalog, and promotional materials were placed in all counseling offices in middle and high schools in the division.

Information on current career academy programs was collected from students through multiple focus groups conducted at each high school. This information, along with a review of the literature, was used to help develop the survey questions that would be included in the student climate survey administered by the school division. The questions were tested for reliability and validity through a pilot survey. A focus group was held with students participating in the pilot survey to determine how students interpreted the questions and to develop a range of answer choices which would accurately capture their thoughts and decisions. The survey included closed-ended questions to determine the attitudes of students towards the 
career academy program and the factors that influenced their decision to apply for and enroll in the program, or decline the career academy option. Permission was obtained from the school division's superintendent, and the department of research, planning, and evaluation conducted the survey through a secure online system.

The school division then shared a data set with the researcher that did not contain any of the students' identifying information. Descriptive statistics were used to analyze the data and measures of central tendency and frequency were used to rank the strength of each factor's effect on students' enrollment or non-enrollment in the career academy program. Further analysis was conducted on each scale of the dataset to examine the strength of correlations between multiple factors which may work together to influence students' enrollment in the career academy program.

\section{Definitions of Terms}

In order to gain a better understanding of this study, the following terms are defined:

- Articulation Agreement: A written commitment that is agreed upon at the State level or approved annually by the lead administrators of a secondary institution and a postsecondary educational institution or a sub baccalaureate degree granting postsecondary educational institution; and to a program that is designed to provide students with a non-duplicative sequence of progressive achievement leading to technical skill proficiency, a credential, a certificate, or a degree and linked through credit transfer agreements between the 2 institutions described (Carl D Perkins Career and Technical Education Improvement Act, 2006, p. 3)

- Career and Technical Education: Organized educational activities that offer a sequence of courses that provides individuals with coherent and rigorous content aligned with 
challenging academic standards and relevant technical knowledge and skills needed to prepare for further education and careers in current or emerging professions; provides technical skill proficiency, an industry-recognized credential, a certificate, or an associate degree; and may include prerequisite courses (other than a remedial course) that meet the requirements of this subparagraph; and include competency-based applied learning that contributes to the academic knowledge, higher-order reasoning and problem-solving skills, work attitudes, general employability skills, technical skills, and occupationspecific skills, and knowledge of all aspects of an industry, including entrepreneurship, of an individual. (Carl D. Perkins Career and Technical Education Improvement Act, 2006, p. 4)

- Career Academy: A small learning community within a public high school program designed for a group of students who take college preparatory courses focused on a particular career pathway and work with local employers and colleges in order to improve student preparation for college and/or the workforce (College and Career Academy Support Network, 2012).

- Career Cluster: Nationally recognized plans of study within a specific career area to allow students to take courses in a sequence that will help prepare them for their chosen career field (Virginia Department of Education, 2012).

- Career Pathways: The skill and knowledge, both academic and technical, necessary to pursue a full range of career opportunities with a pathway - ranging from entry level to management, including technical and professional career specialties (Cotner et al., 2012).

- Programs of Study: Non-duplicative sequences of academic and technical courses that include both secondary and postsecondary level content, opportunities for high school 
students to earn postsecondary credit, and culminate in industry-based credentials or certificates and/or postsecondary degrees (Advance CTE, 2017).

\section{Summary and Overview}

Chapter I discussed the career academy model and how this model can improve student outcomes for college and career readiness. Career academy programs allow students to focus on a specific Career Pathway through all of their coursework, therefore adding meaning to their learning. These programs have been researched and found to be successful in increasing graduation rates, decreasing dropout rates, and increasing test scores (Stern et al., 2010), but research has not been conducted on factors influencing students' decisions to enroll in career academy programs. The academy program also encourages students to attend postsecondary institutions and helps to ensure students are prepared for careers in their Pathway upon high school graduation (Stern et al., 2010). Recruiting and retaining students who have an aptitude

for the specific career field is an important aspect in the development of the career academy, and understanding factors influential in a students' decision to apply for the program can help administrators improve their recruitment methods and program offerings. This study was conducted in an urban school division in the mid-Atlantic area. The study focused on determining the factors that influenced or deterred students' decisions to apply for the career academy.

Chapter II's Review of Literature provides background information on the elements of career academies including Career and Technical Education, Career Clusters, Pathways, and Programs of Study, the career academy concept, and factors influencing high school students. Chapter III discusses the methods and procedures that were used to complete this study. Details of the population, as well as the instrument used to collect data are discussed in this section. The 
findings of this study are detailed in Chapter IV. A final summary of the study with conclusions and recommendations for future research is found in Chapter V. The researcher will address the research questions and discuss implications for future studies. 


\section{CHAPTER II}

\section{REVIEW OF LITERATURE}

A review of literature was conducted to examine the career academy concept and career interests. Chapter II will give an overview of career and technical education, including the history, development, and key legislation. Career Clusters and Career Pathways will then be discussed. Career academies will be described starting with their history and development, followed by the types of career academy programs, research on career academy outcomes, and career academy legislation. It is important for students to explore their career options in order to make decisions about their Career Pathway and career academy. In view of the fact that student choice is important in the career academy model and for this research, factors influencing the decisions of high school students will be discussed at the end of this chapter.

\section{Career and Technical Education}

Training people for the jobs that are available in the community is a part of every culture. This is the purpose of career and technical education (Association of Career and Technical Education, 2016). Career and Technical Education has a long history of working to bridge the gap between education and the workforce (Rojewski, 2002). Career and technical education provides students with career specific skills along with workplace readiness skills (Dougherty \& Fordham, 2016). Workplace readiness skills, such as communication and collaboration, are increasingly necessary as students are adapting to $21^{\text {st }}$ century working environments (Partnership for $21^{\text {st }}$ Century, 2010).

\section{History of Career and Technical Education}

Vocational education, as career and technical education has previously been called, can be traced back hundreds of years. Prior to the nineteenth century, public secondary school 
mainly served the purpose of preparing an elite percentage of the population who completed elementary school for further education. The remainder of students were expected to learn a trade through an apprenticeship (Castellano, Stringfield, \& Stone, 2003). In the nineteenth century trade schools began to develop training, apprenticeship, or a combination of these experiences (Gordon, 2014). Programs were also developed for public schools during this time in the areas of "manual training, commercial training, domestic science, and agriculture," (Gordon, 2014, p. 1). Formal vocational education at the high school level began in schools in the twentieth century (Wonacott, 2003). In 1910 the Commissioner of Education in Massachusetts, David Sneeden, recognized a need for more training to prepare students for work, because this type of training was declining at home. Sneeden developed the areas of vocational education known as professional, commercial, industrial, agricultural, and household arts education (Wonacott, 2003). These vocational programs were most often for students who were considered at-risk of dropping out or not finishing high school (Thompson, 1973). The focus was getting these students training that would allow them to earn a living wage since they would most likely not move on to postsecondary education (Castellano, et al., 2003). One of Sneeden's students, John Prosser, was the author of a report to Congress from a commission to determine if federal aid was needed for vocational education (Hyslop-Margison, 2000). Prosser advocated for vocational training, focusing on specific employability skills, in public schools as a social and educational need and agreed with Sneeden that the industrial social system and class structure was "an inevitable fact of life" (Hyslop-Margison, 2000, p. 4).

Also influential in developing vocational education, but vocal opponent of Sneeden and Prosser, was John Dewey. Dewey viewed education as the platform to prepare students to be productive members of society and to continue to be lifelong learners (Wonacott, 2003). Dewey 
believed that vocational education would be necessary and influential in transforming the current education system (Pautler, 1999). Dewey advocated for vocational education as a part of the comprehensive educational system in order to give students a wide range of options and capacities to expand their occupational opportunities (Hyslop-Margison, 2000).

\section{Career and Technical Education Legislation}

Federal funding for career and technical education dates back to the 1800s. In 1862 the Morrill Act was signed into law, providing federal land for agriculture and mechanic arts education (Library of Congress, 2017). In 1917 the Smith-Hughes Act was signed into law. The Smith-Hughes Act created a separation between vocational education and the rest of the comprehensive high school (Gordon, 2014). It was right after this that America entered World War I and the need for trained workers became essential. World War I and the involvement in wars that followed showed influential leaders in America that vocational education was important, and that training had to continue throughout a person's career (Gordon, 2014). The Smith-Hughes Act provided funding for the position of Commissioner of Vocational Education, which was first held by Charles A. Prosser. Prosser developed 16 theories that "provided a comprehensive foundation for vocational education" (Wonacott, 2003, p. 9). Another important piece of legislation was the Vocational Education Act of 1963. This Act was important because it continued the funding and support for vocational education and also provided "part-time employment for youth who needed the earnings to continue their schooling on a full-time basis" (Gordon, 2014, p. 84).

In 1984 the first authorization of the Carl D. Perkins Vocational Education Act was signed into law. This legislation included "two major goals, one economic and one social" (Gordon, 2014, p. 86). The legislation was designed to create and improve the labor force, as 
well as provide opportunities for education and employment to those who were not deemed college bound (Gordon, 2014). The Carl D. Perkins Vocational and Applied Technology Act of 1990 reflected a focus on the changing economic and educational landscapes (Castellano, et al., 2003). Through this legislation, Tech Prep programs were developed. The Tech Prep program allowed students to "coordinate courses in the last two years of high school with the two-year community college associate degree" (Castellano et al., 2003, p. 246). This Act also initiated the integration of academic and vocational curricula, promoted work-related experiences, and tied funding to accountability (Castellano, et al., 2003). The Carl D. Perkins Vocational and Applied Technology Act of 1990 also required resources to be focused on special populations including economically disadvantaged, disabled, or English language learners (Castellano, et al., 2003). The Carl D. Perkins Vocational and Technical Education Act of 1998 continued to bring changes including "new accountability measures and the treatment of funding for special populations" (Gordon, 2014, p. 104). States had to provide data on the following four indicators as measures of their success and use of their funding: academic attainment and vocational proficiency, completing their diploma and earning a credential or postsecondary degree, placement in postsecondary education, training, military, and/or employment, and participation in nontraditional training and employment (Wonacott, 2003). The emphasis on special populations was reduced in this version of the legislation, but there was a focus on aligning vocational education with local and state reform efforts to help make career and technical education an important part of that reform (Castellano, et al., 2003).

In its most recent reauthorization, the Carl D. Perkins Career and Technical Education Improvement Act of 2006 introduced greater local accountability and programs of study (Brustein, 2006). Programs are required to set targets for identified performance indicators. The 
locality is then responsible for making sure school divisions meet their targets (Brustein, 2006). This requirement comes with sanctions, including the loss of funding, for programs that do not meet their targets. This requires localities to be more strategic when using their funding in order to best meet their targets. Required accountability has made the performance indicators more specific as well. For secondary schools, career and technical education programs must report on standardized testing and graduation rates. Technical assessments must be aligned with industrystandards to show technical proficiency for students. At the postsecondary level there is no more separate measure for academic attainment, but schools must still measure technical proficiency through industry-recognized assessments (2006). Postsecondary schools must now measure student placement in "high-wage, high-skill, or high-demand occupations or professions," (2006, p. 9).

Today, over 12.5 million students in high school and college are enrolled in career and technical education programs (Advance CTE, 2017). Career and technical education continues to receive funding in times of deep budget cuts, and new diploma requirements in many states show the importance of this type of education. However, emphasis on standardized testing and graduation rates often give school administrators a different focus. Career and technical education is moving towards a broader preparation for work, integrating academic and occupational content, and implementing Career Clusters and Pathways (Wonacott, 2003).

\section{Career and Technical Student Organizations}

The development of student organizations in career and technical education is one of the most important aspects of the program. Student organizations in career and technical education are an integral part of a students' experience. The student organizations are known as Career and Technical Student Organizations (CTSOs) and allow students the opportunity to demonstrate 
their skills through leadership, mentorship, internship, competitions, and many other experiences (Alfeld et al., 2007). These organizations are co-curricular and integrated into the related courses and areas of interest (Virginia Department of Education, 2012). The leadership opportunities available through student organizations have enabled members to go on to be leaders in education, business, and public service (Reese, 2011). Research shows that participation in CTSOs can positively influence student achievement and employability skills (Alfeld et al., 2007).

The George-Barden Act of 1946 provided funds for the support of organizations in agriculture (Gordon, 2014). A CTSO for agriculture became officially chartered in 1950 with Public Law 740 (Gordon, 2014). This was "the only act to federally charter a vocational student organization" and it paved the way for the CTSOs that followed in other career and technical education program areas (Gordon, 2014, p. 192). Other CTSOs include Business Professionals of America, DECA, Family, Career and Community Leaders of America, Future Business Leaders of America, Health Occupations Students of America, National FFA, SkillsUSA, and Technology Student Association (Reese, 2011). Evidence has been found that CTSOs can help students stay engaged, improve their grades, and develop strong employability skills (Alfeld et al., 2007). Advisors of CTSOs are career and technical education teachers. These teachers typically spend much of their time and energy to help their students be successful in and outside of the classroom (Reese, 2011). The National Coordinating Council for Career and Technical Student Organizations recognize more than two million student members in CTSOs across the country (2016). CTSOs are an integral part of career and technical education programs and offer business and community partnerships, leadership development, and competitions for student 
members (Alfeld et al., 2007). All of the elements of the student organizations meet the needs of the career academy structure and enable students to expand their classroom learning.

\section{Integration of Academic Content}

Integrating career and technical education courses and concepts into core courses is important in developing a complete education for students and providing relevance for coursework (Meeder \& Suddreth, 2012). Collaboration between career and technical education teachers and core teachers is not always common, but it is a required component of the career academy model (Stern et al., 2010). Career academies have been developing since 1969, and there are currently more than 7,000 career academies in existence today (Stern, et al., 2010). According to the Career Academy Support Network, "a career academy is a type of schoolwithin-a-school or small learning community that provides a college-preparatory curriculum with a career-related theme" (Stern et al., 2010, p. 4). Research has shown that career academies have positive affects for students, which include increased attendance, grades, and graduation rates, along with decreased disciplinary issues (Stern et al., 2010).

\section{Career Clusters and Pathways}

Career Clusters group occupations and industries based on common themes, and Career Pathways focus on career specialties. The expectation is that a Career Cluster prepares students with the knowledge and skills needed for industry regardless of their chosen Pathway, and the Career Pathway prepares students with the knowledge and skills needed for a variety of career options within that Pathway (Association for Career and Technical Education, 2017). The students' program of study identifies their chosen Career Cluster and Pathway, and outlines their path through high school and postsecondary options (Association for Career and Technical Education, 2017). A Career Pathway system provides a roadmap for students to plan their 
education from secondary to postsecondary programs and into their careers, and organizes the information making it more accessible to counselors, teachers, and parents (Torpey, 2015). Creating a Career Pathways system has also been a key event for career and technical education in recent years. Career Pathways have a variety of benefits including; providing context and purpose, focus and flexibility, rigor and relevance, a level playing field, guidance for career selection and foundation for career pursuit, opportunities for interdisciplinary problem-solving and critical thinking, and a foundation for lifelong learning and lifelong earning (Cotner et al., 2012). Career Pathway planning requires a "high level of involvement on the part of employers and community organizations and a commitment to collaboration between secondary and postsecondary educators" (Cotner et al., 2012, p. 3). The career and technical education programs then become a visible integral part of a students' education and training because "highquality (career and technical education) programs incorporate rigorous academic and technical standards, as well as critical workplace skills such as problem solving, communication, and teamwork to ensure career and college success for its students" (Cotner et al., 2012, p. 4). This type of program of study which includes academic and career and technical education courses from secondary through postsecondary is a part of Carl D. Perkins Career and Technical Education Improvement Act of 2006 requirements, and has been a driving force in improving student outcomes (Cotner et al., 2012).

\section{Research in Career and Technical Education}

Published in 2006 by the National Research Center for Career and Technical Education, the Math-in-CTE research study has become one of the most important pieces of recent research for career and technical education. This study focused on creating structured collaboration between career and technical education teachers and math teachers through lesson planning and 
professional development. Math-enhanced lessons were integrated into career and technical education courses for $10 \%$ of the instructional time. Findings showed that students who received math instruction in the context of their career and technical education course performed better on two different math assessments than their peers. The study also showed that implementing the math-enhanced instruction did not take away from the amount of occupational/technical knowledge that was gained in the career and technical education classroom (Stone, Alfeld, Pearson, Lewis, \& Jenson, 2006). A follow-up study conducted during the 2005-2006 school year found that $73 \%$ of the teachers who participated in the original Math-in-CTE study continued using the method and materials from the original study (Lewis \& Pearson, 2007). The study also found that the teachers who were part of the control group and did not receive the professional development to aid in the implementation of the math lessons were not successful in implementing the lesson plans after the initial experiment ended (2007). The Math-in-CTE study was replicated in 2013 with the Science-in-CTE Pilot Study (Pearson, Young, \& Richardson). This study used the same research design as the Math-in-CTE study and found that there was a statistically significant positive impact on students' science achievement in three out of four quartiles (2013). This study is important because it further illustrates the importance of collaborative environments and programs of study. Just as in the career academy model, integrating academic material into the career and technical education classroom provides context for the material and answers the question of when the information will be used in real life.

Research is constantly being conducted through universities and organizations such as the Association for Career and Technical Education Research and the National Research Center for Career and Technical Education. Current research being conducted includes testing student outcomes with programs of study and alternative teacher licensure models. The ever-changing 
economic society forces career and technical education teachers and leaders to constantly study and stay up-to-date on the trends for workforce education. Symonds, Schwartz, and Ferguson of Harvard Graduate School of Education published a study in 2011 called Pathways to Prosperity, which boldly pointed out the need for programs of study and career and technical education. The report examines the United States on a global scale and forces educators to take a hard look at how our students are educated. While it is not always a level playing field when it comes to reporting results globally, the United States has been falling behind other countries in many areas including math and science. Students are starting college in remedial courses and employers are finding that young adults do not have the skills needed for work. These skills include areas such as "critical thinking, problem solving, creativity and communication" (2011, p. 4).

There is a need for more career and technical education courses in secondary education to help prepare students for the workforce and compete in the global economy (Symonds et al., 2011). The focus on college for all is not necessarily the answer. It is important for educators and leaders to look at countries that are successfully implementing career and technical education and academic programs, and learn from their success before our students fall further behind (Symonds et al., 2011). Some European countries recognize the need to provide competency-based education and workplace experience in order to have a better-prepared workforce (European Commission, 2013). The vocational education and training systems that are used include work-based learning as a fundamental aspect of vocational training. Types of work-based learning include apprenticeships, also known as the dual system (Symonds et al., 2013). The educational system should include more influence and support from business and industry, multiple pathways to success, and a new social concept that educating and preparing 
youth is a collective responsibility (Symonds et al., 2011). Federal and state leaders must pay attention to reports and research that demonstrates the need for education reform that moves career and technical education out of the background of a child's education and makes it as important as their core subjects. This begins with legislation, such as the Carl D. Perkins Career and Technical Education Improvement Act of 2006, which requires certain elements and funding for career and technical education.

Hundreds of articles have been published in the area of career and technical education and many reports from organizations such as the Association for Career and Technical Education help to keep educators and leaders informed. The National Center on Education and the Economy (2008) developed a report that provided concepts for education reform. One concept was a performance-based system that required students to take State Board Qualifying Examinations before moving on to the next level. Students could take these exams whenever they were ready and they could be re-taken as many times as necessary. Recruiting highly qualified teachers is also an important focus for school-systems. The concept in this report was that compensation needs to be higher at the beginning of a career instead of the "rear-loaded" system we have now (National Center on Education and the Economy, 2008, p. 61). Another area of particular interest for career and technical education was workforce skills for workers of all ages. This system pointed out the need for continued training, something that every adult needs regardless of his or her career choice (National Center on Education and the Economy, 2008).

\section{Projections for Career and Technical Education}

Education is a critical part of the success of an economy. Reports such as Pathways to Prosperity and the Math-in-CTE study show the need for academic integration and more 
workforce development in secondary schools and the implementation of programs of study. Education and training must be connected to careers that are available in the local community, but "the United States is unable to help people match their educational preparation with their career ambitions," (Carnevale, Smith, \& Strohl, 2010, p. 1). Programs of study and Career Pathways present, and the reauthorization of the Carl D. Perkins Career and Technical Education Improvement Act of 2006 includes, a way to develop a students' educational plan from secondary through postsecondary education and into the students' career based on their career interests. Once there is a plan in place, students can begin to see the relevance of their education for their future. Students do not learn best by sitting for seven hours a day and listening to a teacher lecture (Symonds et al., 2011). Many students learn best through project-based learning and through embedding academic skills "in the presentation of complex workplace problems that students learn to solve" (Symonds et al., 2011, p. 38). Employers also have to become more involved in the education system. Students are being educated for the purpose of becoming productive members of society - the future workforce. Business and industry has to take a more active role in providing funding and opportunities for students to learn about career areas and the education and skills needed to be successful in a career area (Symonds et al., 2011). Career and technical education in the future will need to involve programs of study and input from business and industry in order to be successful (Office of Vocational and Adult Education, 2012). Educators in all areas must also keep up with ever-changing technology in order to keep material relevant and keep students engaged. Students change each generation and the education system must change with the students in order to help prepare them to be a productive part of our workforce (Wilson \& Gerber, 2008). 


\section{Career Clusters, Pathways, and Programs of Study}

In order to focus a students' education on a particular career area a student is interested in pursuing, Career Clusters and Career Pathways, along with programs of study, were developed. According to the Virginia Department of Education, (2012), "a Career Cluster is a grouping of occupations and broad industries based on commonalities" (para. 2). Career Clusters bring career groups together and identify the common knowledge and skills needed to be successful in that career field (Jankowski, Kirby, Bragg, Taylor, \& Oertle, 2009). The National Career Clusters Framework provides 16 Career Clusters and 79 Career Pathways which act as "an organizing tool for curriculum design and instruction" and "a useful guide in developing (programs of study), bridging secondary and postsecondary curriculum, and for creating individual student plans of study for a complete range of career options" (Cotner et al., 2012, p. 151). These Pathways encompass postsecondary education, as well, so that the transition from secondary to postsecondary and into careers is strengthened. Career Clusters help to reorganize curricula around a specific group of occupations that require similar knowledge and skills, although they may be different in the training or degrees required (Torpey, 2015). Career Clusters have and will continue to evolve, but the Current Career Clusters include the following:

- Agriculture, food, and natural resources

- Architecture and construction

- Arts, audio/video technology and communications

- Business management and administration

- Education and training

- Finance

- Government and public administration 
- Health science

- Hospitality and tourism

- Human services

- Information technology

- Law, public safety, corrections, and security

- Manufacturing

- $\quad$ Marketing

- Science, technology, engineering, and mathematics

- Transportation, distribution, and logistics (Cotner et al., 2012)

Within each Career Cluster are a variety of Career Pathways. These Career Pathways are the context for the work-based learning experiences and senior capstone projects that many students will complete during their high school years (Castellano et al., 2003). Nationally, there are 79 recognized Career Pathways that have specific knowledge and skills that are needed to be employed in a more specific career (Jankowski et al., 2009). Each student selects a Career Cluster and Pathway, and then a program of study is developed for the student. The program of study outlines the classes the student will take in secondary and postsecondary education, including academic and career and technical education courses. The programs outline the different ways the student can earn dual enrollment, early college, advanced placement credit, and industry certifications while they are in high school (Jankowski et al., 2009). The program of study enables students to have a plan for their education, and to be able to see how that plan will help them move from secondary education to postsecondary education or training, and finally into the workplace. 
This has also helped to develop the need for a national set of standards in order to produce a competitive global workforce regardless of the district or state that the student comes from. This led to the development of the Common Career and Technical Core (Green, 2012). These standards were designed to align with college and career ready standards, such as the Common Core State Standards in English Language Arts and mathematics, while also incorporating industry standards for the Career Clusters (Advance CTE, 2017). In our assessment-based and data-driven society, career and technical education must be able to show that high-quality teaching and learning is being accomplished.

Career Clusters were developed out of a need to help students be prepared for a workplace that is changing and will continue to change (Wonacott, 2001). The Career Pathways systems were developed to benefit all stakeholders "by offering context, purpose, focus and flexibility, rigor and relevance, a level playing field, guidance for career selection and a foundation for career pursuit, opportunities for interdisciplinary problem-solving and critical thinking, and a foundation for lifelong learning, and lifelong earning” (Cotner et al., 2012, pp. 23). "Career Clusters can help students build Career Pathways by providing the broader, longterm focus on preparation for the workplace" (Wonacott, 2001, p. 3). Clusters allow programs to be organized around a range of occupations, allowing for flexibility and student choice within a large career area. Academic knowledge can be integrated, allowing the students to see the relevance of school to their future career. Career Clusters allow students to be prepared for the career they will eventually enter regardless of their postsecondary plans.

Legislation and policy are a critical aspect of education and preparing the next generation for the workforce. National policy trends and their implementation at the state and local level must be frequently reviewed and updated to maintain the standards needed for business and 
industry. Programs of study are a key element of the Carl D. Perkins Career and Technical Education Improvement Act of 2006. At least one program of study is required to exist in all Perkins-eligible systems because it "appears more likely to improve student outcomes than emphasizing individual elements in isolation, and better promotes transitions to postsecondary education" (Cotner et al., 2012, p. 58). The Association for Career and Technical Education (ACTE) includes the components of academic, technical, and employability skills in their definition of career readiness (Cotner et al., 2012). Programs of study enable career readiness by linking “students' educational experiences through coherent course sequences between the secondary and postsecondary levels" along with linking academic and technical content (Cotner et al., 2012, p. 61). Career and technical education should develop programs of study that focus on foundational concepts in the early grades of secondary education and continue to become more technical as the student moves through high school graduation and beyond. This system is necessary in order to prepare students for both academic attainment and job readiness (Hull, 2003).

Increasing rigor and creating common standards is only a portion of the work that needs to be done. Students have to be motivated and engaged. Education has to reflect the current trends, and students have to see the relevance for their future careers (Roberson, 2013). A key point is that programs of study provide this link and it is a promising step in education reform for career and technical education that these programs of study are now being implemented. Programs of study are a way to close the current skills gap because they are "responsive to the needs of the labor market" (Cotner et al., 2012, p. 71). It is imperative that career and technical education is able to show how the field can help provide benefits to society and a future return on investment because "unless Perkins can clearly demonstrate that its benefits to students, 
institutions, states, and the Federal Government outweigh the federal investment, it remains at risk of having its funding cut in future budgets" (Cotner et al., 2012, p. 70). This is an area that requires constant focus and effort, and programs of study along with Career Pathways provide an opportunity to show the benefits and importance of career and technical programs. The programs of study combine everything that is needed to strengthen the education system including "college and career readiness standards, course sequences, credit transfer agreements, technical skills assessments, and innovative teaching and learning” (Cotner et al., 2012, p. 87). Programs have been implemented into school divisions across the country that include the 16 Career Clusters and 79 Career Pathways. This is a strong start for education reform, but it must continue to receive national attention, legislative support, funding, and professional development at all levels to ensure strong implementation for all students. There is also a need for more longitudinal research to offer quantitative data as proof of the importance and success of these programs in all areas (Cotner et al., 2012). Career Clusters, Career Pathways, and programs of study enable students to outline their education with their future career in mind. There is latitude for students to change their minds, as they will frequently do, but having a plan in place is critical for future success (ACT, 2005).

\section{European Model}

Traditionally, students in European and other countries have been placed into academic or vocational pathways to complete their education. For many years the track a student takes into these types of programs has been determined based on their ability in lower grades.

Students are identified for either university study or for learning a trade (Chmielewski, 2014). This type of tracking can typically take students into separate buildings and places them on two very different paths. Students in a vocational pathway are not eligible for university. In some 
countries tracking can begin as early as age ten with other countries waiting until age 15 .

Parental influence also varies by country, with some countries relying solely on entrance exams. In many countries, the practice of tracking students has become less rigid with more student choice and mobility between tracks (Chmielewski, 2014). However, a changing global labor market and the need for a diverse technologically literate workforce has created new challenges for the educational system. Educational systems are now faced with preparing all students to be a part of a flexible workforce (Werfhorst, 2014).

European countries aim vocational education and training at ensuring their global competitiveness (Brockmann, Clarke, \& Winch, 2008). Vocational education and training in European countries focuses on lifelong learning and employability (Brockmann, Clarke, \& Winch, 2008; Heidemann, 2000). There has been a great emphasis placed on a need to understand the entire labor process and skills such as problem-solving, decision-making, and communication (Brockmann, Clarke, \& Winch, 2008). Vocational training in Europe includes dual systems consisting of classroom courses along with in-company training and a separate system of school-based training. The features of the European model include an understanding that all students should receive a basic vocational qualification, companies must be involved in vocational preparation, and that there should be a three-pronged approach to the training system involving trade unions, employer associations, and the government. This triad approach to the system with management and labor being involved in the education process is one of the features that make the European model different from competing countries (Heidemann, 2000).

With the goal of increasing economic competitiveness and opportunities for young people, the European model includes work-based learning in the forms of apprenticeships and mentorships. European countries contribute a "lack of workplace experience and the related 
skills and competencies" to the skills gap they are facing (European Commission, 2013, p. 4).

Work-based learning includes apprenticeships, on-the-job training periods, and work-based learning that is integrated in a school-based program (European Commission, 2013). This workbased learning is supported through the partnership with management and labor through the Sector Skills Alliances. These alliances help align the skills taught with labor market needs. Members focus on modernizing training, designing and delivering curricula, and improving skills and competence levels (European Commission, 2017). The overall goals are to improve the quality of the training, improve the quality of the teachers, and make the courses relevant to the labor market demands (European Commission, 2017).

\section{Career Academy Concept}

There has been a debate for years about the need for high school reform in the United States and the methods that can be used to accomplish this reform (Tyack, 1974; Kazis, 2005). The Nation at Risk report alerted our society to the immediate need for high school reform to improve academic achievement (United States Department of Education, 2008). Although numerous high school reform efforts have been developed, many never make it to the classroom (Nunnery, 1998), and, out of those that do, more efforts have been tried than have succeeded (Castellano et al., 2003). Addressing academics and career and technical education is essential for the future of high school reform (Kazis, 2005). One method of high school reform that integrates academic subjects with career and technical education is the career academy model. A career academy is a small learning community within a high school that integrates core academic material with career and technical education components in order to provide a career context to the content the students are learning (Stern, Dayton, \& Raby, 2000; Kemple \& Snipes, 2000). Career academies "commonly emphasize innovative instructional strategies that develop high- 
performance work-place skills - project-based learning and cooperative learning, in particular and stress critical thinking and problem solving, all of which have become standards-based priorities for high school achievement" (Orr, 2005, p. 454). Ultimately, instructional content and practices can be altered to include stronger relationships to better engage students. This increased engagement and structure provides improved academic outcomes and more preparation for college and career (Weiss, 1998). Career academies are able to "integrate strategies for student career and college preparation; diversify learning experiences within the classroom and through the workplace; organize learning around a thematic, career-focused curriculum; and prepare all students for college, regardless of their college-going intentions" (Orr, 2005, p. 454). Although there are variations of career academies across the country, the career academy model encompasses three main concepts: small learning communities allowing students to take classes as a cohort with the same collaborative group of teachers; a college-preparatory curriculum with a career theme; and partnerships with employers who can offer student mentorship, internships, and other career-related advice and experiences (Kemple \& Rock, 1996; Kemple \& Snipes, 2000; Orr, 2005; Stern, 2001; Stern, Dayton, Lenz, \& Tidyman, 2002; Stern et al., 2000).

\section{Small Learning Communities}

The career academy model allows students to take a series of courses in small groups with a team of teachers throughout their high school career. Students take their courses together, allowing the teacher to focus content on the career area and students to build bonds within their cohort to support their learning (Stern \& Hoachlander, 2011). Small learning communities have been found to promote greater academic success (Cotton, 2001). Cotton (2001) also discovered that students in small learning communities outperform their peers within the same school. Students reported feeling more secure and safe within their small learning community due to the 
increased level of personalization and involvement (George \& Lounsbury, 2000; Lee \& Smith, 2000). Small learning communities have been looked to as a solution to the lack of motivation of high school students due to its personal and supportive approach (National Research Council Institute of Medicine, 2003). This is likely due to the fact that small learning communities generally provide the supportive environment for students and highly effective work environment for teachers creating a supportive and collaborative setting where student needs and learning can be the focus of the work (Raywid, 1996). The career academy, at its very core implementation, is a small learning community encompassing all of these elements proven to increase student success (Hyslop, 2009).

\section{College-Preparatory Curriculum with a Career Theme}

Preparing students for college or for a career should not remain separate tasks in education. While skills such as communication, mathematic reasoning, reading, and writing are critical to a students' success in postsecondary education, they are also critical to the success in the workplace (Meeder \& Suddreth, 2012). This is the reason that core academic subjects should not remain in their subject-specific departments, but be infused throughout all courses of a students' education (Meeder \& Suddreth, 2012). Career academy programs are one of the models that have been successful in integrating academic subjects with career and technical education (Meeder \& Suddreth, 2012). The career academy incorporates academic courses that not only meet high school graduation requirements and infuse the career theme, but they also prepare students for college entrance requirements and rigorous academic study (Lewis, 1999).

\section{Partnerships with Employers}

Engaging with business and industry leaders in the local community allows students to have experiences in the world of work prior to high school graduation (Stern \& Hoachlander, 
2011). Students are able to interact with business and industry partners through work-based learning experiences. Work-based learning includes cooperative education, mentoring, job shadowing, and school-based enterprises. The focus of work-based learning is to give students experiences in the career field while exposing them to critical thinking skills and project-oriented teaching and learning (Castellano et al., 2003).

\section{History and Development of Career Academies}

The career academy model began in 1969 in Philadelphia, where social turmoil and economic struggles led to innovations in education that linked academic content with a career theme (Hoye \& Stern, 2008). The Philadelphia academies continued to develop through the 1970s and 1980s. Schools in California began using the career academy model in 1981, with an additional goal of preparing students for college (Hoye \& Stern, 2008). This shift in the career academy's focus on dropout prevention to a secondary reform model that could prepare every student for college and career continued through the 1980s (Castellano et al., 2003, Kemple \& Snipes, 2000). Through the 1990s, the amount of career academy programs in the United States increased over 15-fold (Kemple \& Snipes, 2000). Table 1 shows how quickly the California academies and the academies affiliated with the National Academy Foundation grew, beginning in 1969.

School divisions have implemented career academy programs in a variety of ways, while still incorporating the three major elements. One example of a high school career academy program is a school division that has reorganized all high schools into "a ninth grade success academy and career-themed academies for sophomores, juniors, and seniors" (Castellano et al., 2003, p. 260). Each of the academy programs within the school has its own administrator, school counselor, set of teachers, and section of the building. In this type of career academy 
structure, often referred to as wall-to-wall academies, every student is required to enroll in one of the career academies offered in the school or throughout the school division. Key elements of these programs include purity among cohort groups of students and common planning time for the teachers within each academy program (Castellano et al., 2003).

Table 1.

Growth of Three Career Academy Networks

\begin{tabular}{llll}
\hline \multicolumn{1}{c}{ Year } & \multicolumn{1}{c}{ Philadelphia } & \multicolumn{1}{c}{ California* } & National Academy Foundation \\
\hline When Founded & 1969: 1 academy & $1981:$ 2 academies & $1982: 1$ academy \\
1980 & about 5 & -- & -- \\
1985 & about 10 & 12 & 8 \\
1990 & about 20 & 29 & 54 \\
1995 & 28 & 45 & 167 \\
1998 & 28 & 200 & 289 \\
2000 & 29 & 290 & 400 \\
2010 & 28 & 500 & over 500 \\
\hline
\end{tabular}

\section{Research Findings on Career Academy Programs}

Dozens of studies have found positive benefits for students, teachers, and the community as a result of career academies. Students benefit from the career academy approach as measured by improved student engagement, achievement, and post-high school outcomes. Career academies increase student-teacher relationships and student engagement in learning (Kemple, 1997; Kemple \& Snipes, 2000; Maxwell \& Rubin, 2001; Orr, Bailey, Hughes, Kienzl, \& Karp, 2004; Stern et al., 2000). Manpower Demonstration Research Corporation's longitudinal random-assignment study in nine sites of different career academies found that academy students experienced a higher level of interpersonal support than the comparison group (Kemple, 1997). 
Students also increased their career awareness, enhancing their motivation and long-term educational and career goals (Kemple, 1997).

Multiple studies have reported that students graduating from a career academy indicated better teaching and teacher support than their peers. The seniors from these studies reported increased motivation to attend school and apply themselves to their learning (Kemple, 1997; Orr et al., 2004). Students reported a sense of community and support from their teachers and peers. Teaching styles were rated highly, along with meaningful coursework, and an enjoyable experience that students recognized as preparing them for their future in college and career (Kemple, 1997; Orr et al., 2004).

Research has found multiple positive outcomes for students enrolled in career academy programs when compared to their non-academy peers. In a ten-year longitudinal study conducted by the Manpower Demonstration Research Corporation (1993), researchers found that at-risk students participating in the career academy were less likely to drop out of high school and attendance rates were higher than at-risk students not participating in the career academy. At-risk students earned more credits to meet graduation requirements. Students that were likely to graduate without the career academy still found benefits such as an increased likelihood of ontime graduation and an increased enrollment in career and technical education courses without reducing academic course load (Kemple, 1997, 2001; Kemple, Poglinco, \& Snipes, 1999; Kemple \& Rock, 1996; Kemple \& Snipes, 2000). Career academies that provided the strongest support in the early years of high school had the most positive outcomes (Kemple \& Snipes, 2000). This support system included a core group of teachers who taught within the academy and worked together in a cohort, academy students being scheduled together as a group for their classes, and academy courses being housed in a distinct area of the school (Castellano et al., 
2003). Although Kemple (2001) did not find a significant difference in career academy students' college enrollment or employment in comparison to their non-academy peers one year after graduation, he did find that academy students were more successful when they attended a fouryear university in comparison to their non-academy peers. In a study of career academies in one inner-city California school district, Maxwell found that academy graduates were less likely to need remediation and had higher GPAs than their non-academy peers who attended a postsecondary institution (2001). Orr, Hughes, and Karp (2002) also found positive outcomes for academy students in postsecondary institutions in a study of academies that were part of the National Academy Foundation. The study found that academy students whose parents never went to college were going to college at higher rates than the national average and they needed less remediation than their peers (Orr, Hughes, \& Karp, 2002). Studies have also shown that teachers experience higher job satisfaction than their non-academy colleagues (Kemple, 1997).

\section{Career Interest Inventories}

In order for students to make selections on the Career Cluster and Career Pathway they would like to pursue or the career academy they would like to attend, they must determine their career interests. There are many career interest inventories available. Interest inventories have been the dominant way of helping students make decisions about their career paths for years (Harrington \& Long, 2013) and students' interests as early as the ninth grade can be vital in developing the students program of study (Frady, 2005). Students have a large variety of career options, but more and more occupations are requiring some postsecondary education and work experience. Knowing a students' career interest can help to make decisions about the students' program of study and postsecondary options. 
From 1956 to 1974, nine new interest inventories were developed in order to fill the demand by professionals, universities, and companies that were recognizing a need for these instruments (Harrington \& Long, 2013). Numerous devices have been used over the last few decades, but current technology has been able to deliver inventories that can assess abilities along with skills, interests, and self-concepts. Current inventories include the O*Net Ability Profiler, the Ability Explorer, the Harrington-O'Shea Career Decision-Making System, and many more (Harrington \& Long, 2013). These types of career interest inventories can be helpful when students are developing their Programs of Study and selecting their Career Pathways. Although there is not currently research that suggests the influential factors students have for enrolling in career academy programs, career interest inventories may be helpful in determining if the student has an interest in careers related to their selected career academy.

\section{Factors Influencing High School Students}

High school is a critical time for students to explore and determine their career interests. However, students are least academically motivated during their high school years, despite the importance of this time in their education (Wormington, Corpus, \& Anderson, 2012; Williams \& Stockdale, 2004). Students in high school environments have reported feeling alienated and that their school is unresponsive to their needs (National Research Council Institute of Medicine, 2003). Multiple factors for students dropping out of high school have been investigated, such as socioeconomic status, academic achievement, academic self-efficacy, student motivation, and behavioral problems (Alivernini \& Lucidi, 2011). Understanding the factors that influence students and finding programs that can reform the high school environment are critical for the future of education and the future workforce.

Highly motivated students have perceptions that impact their behavior according to the 
self-determination theory (Deci \& Ryan, 2000). Self-determined students can initiate their own actions in order to be successful. Students who are not self-determined need outside influences such as rewards in order to be successful (Alivernini \& Lucidi, 2011). The lowest level of selfmotivation is amotivation. Amotivation involves a student that will not make an effort to accomplish his/her educational goals and feel that he/she cannot change his/her academic outcome (Vallerand \& Ratelle, 2002). A students' self-concept is typically determined by their perception of the opinions of their parents, teachers, and peers. Their self-concept is made up of their self-image, ideal self, and self-esteem (Lawrence, 1996). Students who have a high selfconcept are often more influenced by internal factors which can lead to a very successful academic career (Alivernin \& Lucidi, 2011). Although this is most often the case, high selfconcept cannot always indicate academic success just as low self-concept cannot always indicate academic failure (Alivernin \& Lucidi, 2011).

For a student with external regulation, all of the factors influencing their behavior are associated with tangible results that are considered to be positive or to avoid a negative result (Deci \& Ryan, 2000). Students who are influenced by external factors will be looking for what they get out of doing a task or getting a good grade. Intrinsic regulation is considered to be the highest level of self-determination. This is when students are able to complete tasks and assignments because they find them interesting (Deci \& Ryan, 2000). A student that is intrinsically motivated will be able to seek out tasks and challenges in order to explore and learn new things and to reach a desired outcome (Deci \& Ryan, 2000). These students do not need rewards; they simply want the satisfaction of knowing they accomplished something (Lawrence \& Vimala, 2013). The behavior of intrinsically motivated students is coming from within themselves, so this behavior is likely to extend over long periods of time (Alivernini \& Lucidi, 
2011).

Teachers work with students from all aspects of the motivational spectrum. Many students come to school unwilling and unmotivated to complete their assigned tasks or even listen in class (Hidi \& Harackiewicz, 2000). Teachers can have a negative impact on students' self-determination. Negative effects on student self-determination include controlling behavior, monitoring too closely, and not giving students the opportunity to make choices or express their opinions (Reeve, 2002). Positive actions from teachers, such as giving students choices, listening to them, and letting them express their opinions, can increase a students' selfdetermination (Reeve, 2002).

Parental influence has been found to be a significant predictor of a child's success in school (Jeynes, 2012). Parents who are considered supportive and emotionally involved tend to have students who are more intrinsically motivated. Parents who are controlling and commanding tend to have students who have less self-regulation or are more extrinsically motivated (Grolnick, Ryan, \& Deci, 1991). The more involved the parents are, the more likely the student is to be successful through high school. Parental involvement can also impact a students' postsecondary and career interests. Whenever possible, decisions about a students' education and their career should be made with parental influence (Hoyt, 1984). The primary role model for a child through their secondary education is their parent. The parent has influence over the students' career exploration both directly and indirectly through modeling, experiences, and discussions. Parental influence and student decision making can also be impacted by perceptions of various careers, socioeconomic status, the parent's educational attainment, and other environmental influences (Levine \& Sutherland, 2013). 
Decisions for students continue after they reach the college level, where they must decide on a college major. Choosing a college major is a huge life decision and can be cause of major emotional and physical distress (Beggs, Bantham, \& Taylor, 2008). Many studies have found a variety of reasons that influence the choice of a college major. Chung, Loeb, and Gonzo (1996), along with Keillor, Bush, and Bush (1995), found that parental influence has a significant effect on major choice. One study found that the highest rated factor influencing the selection of a college major was a genuine interest in the subject (Leppel, Williams, \& Waldauer, 2001). Other factors influencing the selection of a college major can include sources of information, job characteristics, fit and interest in the subject, and characteristics of the major or degrees (Beggs et al., 2008).

\section{Summary}

Career and technical education has grown and changed to now encompass preparing students for the skills they will need to be successful regardless of their postsecondary plans. Various school improvement efforts have been made in an attempt to increase graduation rates and abilities of the youth in the United States. One of those efforts is the career academy. Career academies can help improve student outcomes and put students on a pathway to make their education more meaningful and successful. Chapter II discussed the literature about career and technical education, Career Clusters and Pathways, career academies, career interest inventories, and factors that influence high school students. There is a need to further investigate the factors that influence high school students to apply and enroll in the career academy program to determine if they are interested in pursuing the career area of the career academy. Further, there is a need to investigate why students choose not to enroll in career academy programs that are offered to them. Examining why students enroll and why they choose not to enroll in career 
academy programs can be influential in the development of and recruitment for future program offerings. Chapter III will present information about the study's methodology. 


\section{CHAPTER III}

\section{Methodology}

Chapter III provides an explanation of the methods and procedures that were used to conduct this research study. This research used a quantitative approach to investigate the relationship between factors influencing high school students' enrollment in career academies, in order to identify ways to improve academy recruitment and the development of academy program offerings. This chapter will discuss the population, design, measures, procedure, and analysis of the study.

\section{Purpose Statement}

The purpose of this study was to assess the factors influencing students' decisions to enroll in career academy programs.

\section{Research Questions}

The research questions addressed in this study were as follows:

$\mathrm{RQ}_{1}$ : What factors influence students to apply for career academy programs?

$\mathrm{RQ}_{2}$ : What reasons do students have for choosing not to enroll in a career academy?

Research question one aimed to identify the factors that influence student enrollment in career academy programs. Research question two aimed to identify factors that influence students who do not enroll in career academy programs. This information can then be used to develop recruitment and retention initiatives along with developing academies that meet the needs of the students they serve.

\section{Sample}

The participants of this study were ninth through twelfth grade students enrolled in comprehensive high schools in an urban school division in the mid-Atlantic. For confidentiality, 
the school division is not identified in this study. The school division supports over 20,000 students from Pre-K through $12^{\text {th }}$ grade (Virginia Department of Education, 2016). Each of the high schools operates a career academy program. The career academy programs include a variety of Career Clusters and Career Pathways.

This study examined existing 2016 survey data provided by the school division to address the research questions. The school division in this study has been operating career academy programs in each of its comprehensive high schools for more than four years. According to the Career Academy Support Network, "a career academy is a personalized small learning community within a high school, selecting a subset of students and teachers for a two-, three-, or four-year span.” (n.d., para. 1).

Out of the total high school population of 5,615 students, the division reported that 485 were enrolled in a career academy program in 2016. All high school students had the opportunity to apply for a career academy program at any of the high schools.

\section{Research Variables}

The independent research variable was whether or not the students were enrolled in a career academy program. The dependent variables for research question one were the factors which influence students to enroll in a career academy and the gender of the student. The influential factors for enrolling in a career academy were further categorized into intrinsic and extrinsic factors. The dependent variables for research question two were the factors which influence students not to enroll in a career academy, along with the gender and age of the student. 


\section{Instrument}

\section{Instrument Development}

Near the end of the first semester of the school year, the school division annually conducts a student climate survey. The school division knew that the perceptions of students on issues such as cleanliness and safety could impact attendance, behavior, academics, and division enrollment. The purpose of the survey was to measure the perceptions of students and use their feedback to generate action plans for school improvement. Survey questions were developed in collaboration with a research team from K12Insight assigned to provide support to the division. K12Insight is a consulting firm focused on helping school divisions conduct research and create strategies to improve customer service, communication, and school climate (K12Insight, 2017). The division leadership team generated a list of topics and the K12Insight team created the survey questions. All division research is led by the division's Director of Research, Planning, and Evaluation.

In 2012, the division did an extensive review of the survey and development strategies and made changes to both the instrument and how it was administered. The division was concerned about receiving actionable information from students while also preserving instructional time. As a result, the survey now includes 12-15 questions that all respondents answer and uses logic functions to get detailed information from respondents who indicate that the division needs improvements in one of the identified areas. The survey includes questions in the following categories:

- Academic practices

- Parent involvement

- School safety 
- Emotional safety, adult support, and cultural competence

- School cleanliness

- School maintenance

- School food and nutrition

- School transportation

- Use of technology for instruction

The division has three specific goals when reviewing survey results. The first is using student information to drive improvement planning in areas where the school division has control. The next designated use of the survey is improvement planning at the building level. Finally, the division uses climate survey results in research. Through the survey platform, response data can be linked to other student data such as attendance, behavior, and academics. In this way, the division can analyze data to discern which areas of climate have a stronger association with other outcomes to further target improvement efforts.

For the 2016-2017 student climate survey, questions were included to gather data about the current career academy program. The division was planning to expand its career academy offerings and was looking to gather information on student perceptions of the academies, students' reasons for applying, student awareness of academy programs, and career interests of current students. The 2016-2017 high school Student Climate Survey can be found in Appendix A.

To determine the dependent variables and formulate the questions for the survey instrument, the school division's department of research, planning, and evaluation conducted semi-structured focus group interviews with students in each of the high schools. Focus groups were conducted with current academy students from all grade levels, as well as students from all 
grade levels who were not currently enrolled in a career academy. The focus groups were conducted over the course of two school days. Academy teachers were asked to allow eight to 10 students from each grade level to participate in the focus groups at specified times in the morning. In the afternoon, non-academy teachers were asked to allow eight to 10 students from each grade level to participate in the focus groups at specified times. Students were randomly selected to attend the focus group sessions.

Each focus group session lasted approximately 20 minutes and began with an overview of the purpose of the focus group. The students were then asked a series of questions regarding their knowledge of the career academies, their experiences within the academies, and their reasons for enrolling or not enrolling in the career academies. They were also asked about career interests for the purposes of developing future academies and what would make them want to enroll in future academies. The same procedure was used the second day at another high school. Each focus group included students from each grade level both from the career academy and from the general student population in the high school.

\section{Establishing Validity and Reliability}

The focus groups were coded by the school division to discover the influential factors students had for enrolling in the career academy. Due to the limited amount of quantitative research available on this topic and the lack of an extant reliable instrument, the data from the focus groups were used to create the survey instrument, providing some face validity that the survey items were authentic and measured what they were supposed to measure. Once the initial instrument was created, the school division conducted a pilot survey with a small group of academy and non-academy students in order to test the discriminant validity of the data collected via the survey. Researchers met with eight students from each high school who were in the 
academy program and eight students from each high school who were not in the academy program. Students were from all four high school grade levels. None of these students participated in the first round of focus groups. Each group of students included students from each grade level in both the career academy and the general population in the high school.

During each 20-minute session, the students took the pilot survey on computers in the classroom. After students took the appropriate version of the survey, they were asked questions about their understanding of the survey and the answer choices included in the survey. Students were queried to see if they understood what was being asked of them. They were also questioned to see if there was anything else that should have been asked on the survey. Students were asked if the language used was clear and thorough. No student expressed confusion over the content or offered an answer indicating they were confused. The pilot survey suggested that two questions be combined. One question asked if students knew about the academy or not and the next question asked for reasons that they did not apply. The pilot survey groups suggested that not knowing about the academy could be listed as a reason that they did not apply.

Researchers from the school division's department of research, planning, and evaluation conducted the pilot survey with focus groups from each high school in order to validate that the instrument measured what it was supposed to measure reliably. During each session, all the participants agreed that the survey instrument was easy to read and understand, that the questions were clear, and the answer choices were appropriate. Students indicated that there was not anything that they would change about the survey and that the language was clear. Students felt that their peers would be able to understand the intent of the survey answer the survey questions. Feedback from each group of students was consistent and endorsed the influential factors used as answer choices, establishing sufficient reliability for the instrument to be administered to the 
broader population during the annual survey period.

\section{Survey}

In the 2016-2017 student climate survey, students were asked to identify if they were currently enrolled in a career academy program or not. Using a differentiated logic function, the survey directed them to a set of questions based on academy enrollment. If they were enrolled in an academy program they were taken to a set of questions about the academies. If they indicated that they were not enrolled in an academy program they were taken to a set of questions about their reasons for not enrolling. Non-academy related questions and responses from these questions were not shared with the researcher.

The survey questions related to the career academies were Questions 5 through 10, with the exception of Question 7 (Table 2). Question 5 first asked if the student was currently enrolled in a career academy. Students could select one response from a list of the current academies in the division or a choice to indicate that they were not currently enrolled in an academy. The survey instrument then incorporated a logic function to direct students to the appropriate questions based on their previous responses. If students indicated in their answer to Question 5 that they were currently enrolled in one of the existing career academy programs, they were directed to survey Questions 8 through 10. Question 8 asked how the student learned about the career academy, and the student could indicate any or all of the applicable responses from the list developed during the focus groups conducted prior to the survey. These 13 responses included parents, siblings, teachers, school counselor, principal/assistant principal, other students, middle school career fair, rising $8^{\text {th }}$ grade parent night, website, course offering guide, announcements, brochures, or other. 
Table 2

Career Academy Survey Questions

\begin{tabular}{|c|c|c|}
\hline $\begin{array}{l}\text { Question } \\
\text { Number }\end{array}$ & Survey Question & Response Choices \\
\hline \multirow[t]{6}{*}{5} & Are you currently in & Choose One Response \\
\hline & a career academy? & $\circ$ Academy A \\
\hline & & - Academy B \\
\hline & & ○ Academy C \\
\hline & & $\circ$ Academy D \\
\hline & & $\circ$ I am not in a career academy \\
\hline \multirow[t]{9}{*}{6} & Why didn't you apply & Check all that apply \\
\hline & for a career & $\circ$ I didn't know about the academies \\
\hline & academy? & I'm not interested in those careers \\
\hline & & $\circ$ The application was too long/hard \\
\hline & & $\circ$ I missed the application deadline \\
\hline & & - I did not have transportation to the program that interested me \\
\hline & & $\begin{array}{l}\text { I did not want to leave my zoned high school to attend a } \\
\text { different academy }\end{array}$ \\
\hline & & I I applied, but was not accepted \\
\hline & & o Other: \\
\hline \multirow[t]{14}{*}{8} & How did you learn & Choose all that apply \\
\hline & about the career & ○ Parents \\
\hline & academy & ○ Siblings \\
\hline & & $\circ$ Teachers \\
\hline & & ○ School Counselor \\
\hline & & ○ Principal/Assistant Principal \\
\hline & & - Other Students \\
\hline & & ○ Middle School Career Fair \\
\hline & & $\circ$ Rising $8^{\text {th }}$ Grade Parent Night \\
\hline & & ○ Website \\
\hline & & $\circ$ Course Offering Guide \\
\hline & & ○ Announcements \\
\hline & & $\circ$ Brochures \\
\hline & & O Other: \\
\hline \multirow[t]{6}{*}{9} & $\begin{array}{l}\text { Why did you apply } \\
\text { for the career }\end{array}$ & $\begin{array}{l}\text { Rate the importance of each item (Select very important, somewhat } \\
\text { important, slightly important, or not important) }\end{array}$ \\
\hline & academy? & $\circ$ I am interested in the career field \\
\hline & & I I wanted to go to the school where the academy is located \\
\hline & & - My parents wanted me to apply \\
\hline & & - It will look good for college applications \\
\hline & & $\circ$ I thought it would be fun \\
\hline \multirow[t]{6}{*}{10} & $\begin{array}{l}\text { Career academy } \\
\text { experiences should }\end{array}$ & $\begin{array}{l}\text { Rate the importance of each item (Select very important, somewhat } \\
\text { important, slightly important, or not important) }\end{array}$ \\
\hline & be different from & $\circ$ Being in classes with other academy students \\
\hline & traditional high & - Hands-on learning in the context of my career interest \\
\hline & $\begin{array}{l}\text { school. How } \\
\text { important are these }\end{array}$ & $\begin{array}{l}\text { - Attending activities and events outside of school related to the } \\
\text { academy }\end{array}$ \\
\hline & features in your & ○ Work experience outside of school related to what I am learning \\
\hline & academy experience? & Other: \\
\hline
\end{tabular}


Question 9 asked the student why he/she applied for the career academy. Students were able to indicate the degree of importance (very important, somewhat important, slightly important, and not important) on a four-level Likert-type scale for each potential reason that they applied to the career academy. Lozano, Garcia-Cueto, and Muniz (2008, p. 73) showed "that the optimum number of alternatives is between four and seven. With fewer than four alternatives the reliability and validity decrease, and from seven alternatives onwards, psychometric properties of the scale scarcely increase further." The five potential reasons included: an interest in the career field, wanting to go to a particular school, parental influence, college applications, and the perception of the academy as being something fun to be a part of. Survey Question 10 explained that career academy experiences should be different from traditional high school experiences, and again asked students to indicate the degree of importance (very important, somewhat important, slightly important, and not important) on the same four-level Likert-type scale for each feature of a career academy. The five features included: being in classes with other academy students, hands-on learning experiences in the context of career interest, attending activities related to the academy outside of school, work experience outside of school related to the academy, and other. Responses to survey Questions 8, 9, and 10 were used to answer Research Question 1.

If the student indicated that he/she was not in a career academy in his or her response to Question 5, he/she was taken to Question 6, which asked why the student did not apply for a career academy. Students were able to select from the reasons developed during the focus groups conducted prior to the development of the survey. The eight potential responses included: not knowing about the academies, not interested in the careers the academies focus on, the application process, the application deadline, transportation, having to leave their zoned 
school, not being accepted, and other. The student was then directed to survey Question 7, which was not used for this study, but asked the student to indicate the degree of interest on a three-level Likert-type scale (very interested, somewhat interested, and not interested) in the career fields that would interest them for future academies. Survey Question 6 was used to answer Research Question 2.

\section{Data Collection}

The division launched the student survey on December 5, 2016, and students had until December 20, 2016 to complete the survey. The link to the online survey was sent to all current high school students through their division email address. Students were encouraged to complete the survey through email reminders and from their teachers during various classes. The school division collects each students' school email address along with his or her survey response, but the division does not release individual responses. Students were informed that their decision to complete the survey was voluntary and participation would not have an impact on their grade or standing with the school. The data collected from the career academy questions in the survey were extracted by the school division and an aggregate file was created to share with the researcher. The data set was provided in such a way that it did not include any student identifying information. All of the career academy questions in the student climate survey required a response. The researcher completed an application to have the research proposal reviewed and approved by the Institutional Review Board (IRB) to ensure ethical principles were followed regarding responsibility to participants in this study. The research was approved as an exempt study by the IRB at the degree granting institution. The final data sample included responses from $n=401$ students enrolled in a career academy program and $n=2,421$ students not enrolled in a program, with descriptive data of age and gender. 


\section{Data Analysis}

Various statistical procedures were followed to assess the data. The statistical software SPSS was used to organize and analyze the data from the study. Descriptive statistics were examined to review the nature of the factors influencing students to enroll or not enroll in the academy programs. Measures of central tendency and frequency were used to identify which variables had more than a weak association with student enrollment in the career academy program $\left(\mathrm{RQ}_{1}\right)$, and which variables had an association with students' decisions not to enroll in the career academy program $\left(\mathrm{RQ}_{2}\right)$. The data were also examined for normality and consistency. This analysis also included examining whether there were any significant group differences due to gender.

Using JASP, an open-source statistical analysis platform supported by the University of Amsterdam, various exploratory factor analyses (EFA) were completed to investigate the various factors previously identified as relevant to students' decisions to either enroll or not to enroll in the career academy program and identify themes within the factors. To determine the loading of each factor, a single scale exploratory factor solution was first forced on each scale using maximum likelihood (ML) extraction, and any factor with weak loading $(<0.4 ;$ Costello \& Osborne, 2005) was eliminated from the items for future surveys. Additional EFAs were then conducted on the overall data for all scales in each relevant sample (enrolled/not enrolled), allowing the software to define the number of factors in the model using eigenvalues $(>1)$, scree plots, or other factoring methodology resulting in the best fit. The resulting factors provided a starting point for developing career academy program improvements. A Pareto analysis was conducted to identify relevant responses for how students learned about the career academies 
that were available to them and to examine the reasons non-academy students did not apply for career academy programs.

\section{Summary}

Chapter III discussed the methodology that was used to conduct this study and address the research questions. This chapter described the research purpose, population, research variables, instrument used, data collection, and data analysis of the research. Chapters IV and V will discuss the findings of the study, conclusions, and recommendations for future research. 


\section{CHAPTER IV}

\section{Findings}

The purpose of this study was to assess factors influencing students' decisions to enroll in career academy programs. The research questions addressed in this study were as follows:

$\mathrm{RQ}_{1}$ : What factors influence students to apply for career academy programs?

$\mathrm{RQ}_{2}$ : What reasons do students have for choosing not to enroll in a career academy?

A survey conducted by the school division was used to collect the necessary data. The collected data were analyzed to address the research questions and the results of the analyses are included in this chapter.

\section{Response Rate}

The survey was open to all ninth through twelfth grade high school students enrolled in the school division from December 5, 2016 through December 20, 2016. Students received access to the survey through a link sent to their school email address. There were 3,258 responses to the survey from the high school students which had been validated by the division. The responses included students enrolled in alternative programs within the division. Since these students did not have the option of selecting a career academy, the researcher elected not to include them in this study, removing these 67 responses from the data set. There were 648 high school students who reported that they are in a career academy program, 2,610 students who were not in a career academy program, and 189 students who did not respond to the question about career academy enrollment. The records from these 189 students were removed from the data set. 


\section{Data Screening}

Data were examined for completeness and consistency within scales. There were 6,331 records in the original file. Of these, 3,073 records were from students who were currently enrolled in middle school and not part of this study. This left $N=3,258$ records as the total sample for this study. After removing records where students did not respond to every question, along with middle school data, there were $n=423$ records remaining of students who were participating in a career academy and $n=2,421$ records for non-academy high school students.

For the academy dataset, there were 22 cases with disconnects between the school they attended and the career academy they reported. In these instances, the students selected a career academy that was at a different school than the one they attended. These records were removed to ensure career academy participation was identified correctly in all included records. The remaining $n=401$ records were included in the analyses of students currently enrolled in a career academy. This data screening process was repeated for students who were not participating in a career academy, leaving $n=2,421$ records included in the analyses of students not currently enrolled in a career academy.

\section{Transformations}

The data to be analyzed were divided into two sets: the records of those attending any of the four career academies and those who did not. Common variables between the two sets included age, race, sex, GPA, and earned credits. GPA, age, and earned credits were the only continuous variables in either dataset; all others were categorical, including the data responses that were needed to answer the research questions.

Factor analysis is a parametric procedure that assumes normal data on a continuous data scale. In order to perform a factor analysis on discrete data, different assumptions must be made 
and/or the data must be transformed to continuous data. Data transformation is recommended by many social researchers for attitudinal data which is often categorical. To complete a factor analysis, Kolenikov and Angeles (2004)

...believe that the researcher will be better off using the ordinal variables as inputs to PCA. If the variables do not come in a "standard" way such as $1,2, \ldots$ (Likert scale) with roughly equal distances between categories, it is worth recoding them that way, so that those distances are not very different. (p. 35)

They discuss using a Principal Component Analysis (PCA) compared to polychoric correlation matrix to accomplish factor analysis and state that "the only reason to prefer one of the methods seems to be the proportion of explained variance, which is reported correctly only by the polychoric method" (p. 36). Since this study was intended to report the influences and not to build a predictive model for high-stakes evaluation, conducting an exploratory factor analysis (EFA) using the PCA method was deemed suitable.

Recoding. Each of the academy and non-academy datasets were comprised of item responses that needed to be recoded to run statistical analyses. There were a total of $n=22$ items collected from academy students $(n=401)$ between three survey questions $(8,9$, and 10$)$. There were a total of $n=8$ items collected from non-academy high school students $(n=2,421)$ in survey question 6.

Data analysis. Factor analysis was conducted on the Likert-type item responses from question 9 and $10(n=9)$. The factor analysis was conducted on these responses since they could be treated as continuous data. Pareto analyses were conducted on the data from questions $8(n=13)$ and $6(n=8)$. 
Factor analysis. The data transformation for the factor analysis to address research question 1 (What factors influence students to apply for career academy programs?) comprised recoding each of the four possible rating responses (Very important, Somewhat important, Slightly important, and Not very important) to survey question 9 (Why did you apply for the career academy?) as a scale integer between 1 and 4 for each of the respective identified factors. A similar transformation was applied to the responses from survey Question 10, which asks students to rate the importance of several features to their academy experience. The mean for each factor was then calculated and used to fill missing responses in each scale.

Data adequacy. The internal consistency for the Likert-type data consisting only of the five items from survey Question 9 was $r=0.63$ and, for the four items from Question 10, $r=$ 0.69, both less than desired for further analysis. Due to the similar nature of Questions 9 and 10, i.e., the first measuring the relative importance of supplied reasons for choosing the academy in the first place, while the second rates the importance of supplied features in their actual experience, the researcher consolidated the two scales (Questions 9 and 10) to evaluate them together as a possible measure of influence that might apply to future students' choices. This rendered the data consistent for further analysis $(r=0.70)$. See Table 3 for descriptive statistics for the combined Likert-type dataset for research question 1.

Table 3.

Importance Academy Students Give for Best Features of and Reasons They Choose Career Academies, Ranked $(r=0.704$, average inter-item correlation $=0.224)$

\begin{tabular}{|c|c|c|c|c|c|}
\hline & M & SD & Skewness & Kurtosis & $\begin{array}{l}\text { Inter-item } \\
\text { Correlation }\end{array}$ \\
\hline Hands-on learning in the context of my career interest & 3.700 & 0.610 & -2.636 & 8.140 & 0.435 \\
\hline Work experience outside of school related to what I am learning & 3.533 & 0.718 & -2.054 & 4.655 & 0.416 \\
\hline Attending activities and events outside of school related to the academy & 3.429 & 0.845 & -1.776 & 2.675 & 0.408 \\
\hline I am interested in this career field & 3.416 & 0.899 & -1.521 & 1.345 & 0.451 \\
\hline I thought it would be fun & 3.212 & 0.978 & -1.063 & 0.025 & 0.434 \\
\hline Being in classes with other academy students & 3.161 & 0.940 & -1.236 & 0.783 & 0.347 \\
\hline It will look good for college & 3.469 & 0.845 & -1.586 & 1.672 & 0.379 \\
\hline I wanted to go to the school where the academy is located & 2.863 & 1.163 & -0.535 & -1.206 & 0.375 \\
\hline My parents wanted me to apply & 2.726 & 1.086 & -0.332 & -1.175 & 0.262 \\
\hline
\end{tabular}


Discrete data. The responses from survey Questions 6 and 8 were multiple choice and the respondent could select as many as applied, so the responses were re-coded with a numeric value of 0 (unchecked) or 10 (checked) to create dummy variables using continuous data. The internal consistency and item-rest correlation for the relevant datasets were well below 0.70 . This indicates a low correlation between items, which further suggests issues with model construct, so factor analysis was not recommended for these data, but rather Pareto analysis and $t$-tests for significant differences between male and female students were conducted.

Composite scores. Composite scores for responses to survey questions 6 and 8 were created by summing factor means by counts for sex and race to generate group means. These group means were then analyzed using a paired samples $t$-test to determine whether there were significant differences between groups. See Tables 4 and 5 for descriptive statistics for the academy and non-academy datasets, respectively.

Table 4.

Factors Academy Students Selected for How They Learned about Career Academies, Ranked $(r=0$, average interitem correlation $=0.224)$

\begin{tabular}{lrrrr}
\hline & & & & Inter-item \\
& $M$ & Skewness & Kurtosis & Correlation \\
\hline Counselor & 6.035 & -0.425 & -1.829 & 0.100 \\
Parents & 3.965 & 0.425 & -1.829 & 0.101 \\
Teacher & 3.865 & 0.468 & -1.790 & 0.250 \\
Other students & 2.793 & 0.988 & -1.030 & 0.257 \\
Catalog & 1.895 & 1.590 & 0.532 & 0.226 \\
Website & 1.521 & 1.945 & 1.790 & 0.141 \\
Brochure & 1.721 & 1.744 & 1.047 & 0.207 \\
Announcements & 1.646 & 1.816 & 1.304 & 0.326 \\
Rising 8th Grade Parent Night & 1.621 & 1.841 & 1.395 & 0.158 \\
Siblings & 0.973 & 2.729 & 5.473 & 0.089 \\
MS Career Fair & 1.047 & 2.591 & 4.738 & 0.149 \\
Principle/VP & 0.848 & 2.992 & 6.989 & 0.174 \\
Other & 0.274 & 5.808 & 31.894 & -0.106 \\
\hline
\end{tabular}


Table 5.

Reasons Why Non-Academy Students Do Not Attend Career Academy, Ranked $(r=-1.22$, average inter-item correlation $=-0.03)$

\begin{tabular}{lcrrr}
\hline & & & & $\begin{array}{c}\text { Inter-item } \\
\text { correlation }\end{array}$ \\
\hline I didn't know about the academies & $M$ & Skewness & Kurtosis & -0.476 \\
I am not interested in those careers & 4.581 & 0.168 & -1.973 & -1.887 \\
I missed the application deadline & 4.168 & 0.338 & -0.501 \\
I did not want to leave my zoned high school & 1.165 & 2.392 & 3.727 & -0.170 \\
Other & 1.161 & 2.399 & 3.757 & -0.021 \\
I did not have transportation to the program & 0.913 & 2.840 & 6.070 & -0.384 \\
I applied, but was not accepted & 0.516 & 4.055 & 14.450 & 0.118 \\
The application was too long/hard & 0.306 & 5.458 & 27.810 & -0.132 \\
\hline
\end{tabular}

For the academy dataset, there were a total of $n=22$ item means that influenced students. These 22 characteristics represent the possible universe of responses to research question 1 , "What factors influence students to apply for career academy programs?" For the non-academy dataset, there were $n=8$ items that addressed research question 2, "What reasons do students have for choosing not to enroll in a career academy?"

Face validity. Although several of the academic items were removed during the factor analysis due to low loading, from a validity standpoint, it is important to examine at the outset how different groups' data behave in different contexts to demonstrate data congruency (i.e., that the data behave the way one expects them to behave when examined by group). For instance, in a normal population, one might reasonably expect that there are differences between sexes in career influences, which could potentially carry over to career academies and their influences and desirable features. If there are significant differences in the composite influence means by sex, that demonstrates data congruence - the data revealed what you thought they would, in accordance with your conceptualization of the model. 


\section{Statistical Analyses}

A paired two-sample $t$-test was conducted to compare male and female means for group composite scores for the 22 items included in survey questions 8,9 , and 10; there was a significant difference between male and female responses $t(21)=1.91, p=0.035$. Further examination of the composite dataset indicated that the between-sex difference arose from the Hispanic and Black subgroups, with differences $t(21)=1.74, p=0.048$ and $t(21)=1.81, p=$ 0.042, respectively. There was no significant differences between sexes for non-academy students' composite scores for reasons for not applying, although there were significant differences between sexes in the individual reasons of Interest $t(2195)=-2.41, p=0.008$, Rejected $t(2381)=2.02, p=0.023$, and Application Difficulty $t(1777)=-2.21, p=0.014$, with girls reporting Not Interested and Application Difficulty less frequently as reasons for not applying, and being Rejected more frequently.

Research question 1. To address the first research question regarding the factors influencing students to apply for a career academy program, a factor analysis was conducted on responses to survey Questions 9 and 10. Prior to analysis, factors with inter-item correlations less than 0.40 were removed from the combined set as long as their removal did not reduce the dataset reliability below 0.70 , leaving in just the top six items from Table 4.

Using JASP, a free statistical analysis application from the University of Amsterdam, an exploratory factor analysis was performed on the remaining six factors to test both one- and twofactor solutions, as shown in Table 6. Testing for a one-factor model, with the item 'I thought it would be fun' was removed due to weak loading, resulted in a poorer fit than the two-factor model. Figure 2 shows path diagram and factor loadings for the best fit two-factor solution. 
Table 6.

Data Adequacy and Goodness-of-Fit of Academy EFA Model Using Questions 9 and 10 Data

\begin{tabular}{lcccccc}
\hline & $\begin{array}{c}\text { KMO } \\
\text { Measure } \\
\text { of Sampling } \\
\text { Adequacy }\end{array}$ & $\begin{array}{c}\text { Bartlett's } \\
\text { test } \\
\text { of } \\
\text { sphericity }\end{array}$ & $\chi^{2}$ & $\chi^{2} / d f$ & RMSEA & $\begin{array}{c}\text { Tucker- } \\
\text { Lewis } \\
\text { Index }\end{array}$ \\
\multicolumn{1}{c}{ Threshold/cutoff } & $>.70$ & $p<.05$ & $p>.001$ & $<5$ & $<0.08$ & $>.90$ \\
$\begin{array}{l}\text { Model } \\
\begin{array}{l}\text { Two-factor model (six } \\
\text { variables, } n=401 \text { ) }\end{array}\end{array}$ & 0.70 & 0.001 & $\begin{array}{l}6.549, \\
p=.162\end{array}$ & 1.625 & 0.04 & 0.98 \\
$\begin{array}{l}\text { One-factor model (five } \\
\left.\text { variables }{ }^{1}, n=401\right)\end{array}$ & 0.70 & 0.003 & $\begin{array}{l}21.480, \\
p=.000\end{array}$ & 4.296 & 0.09 & 0.91 \\
\hline
\end{tabular}

1 'Fun' factor was removed due to weak loading

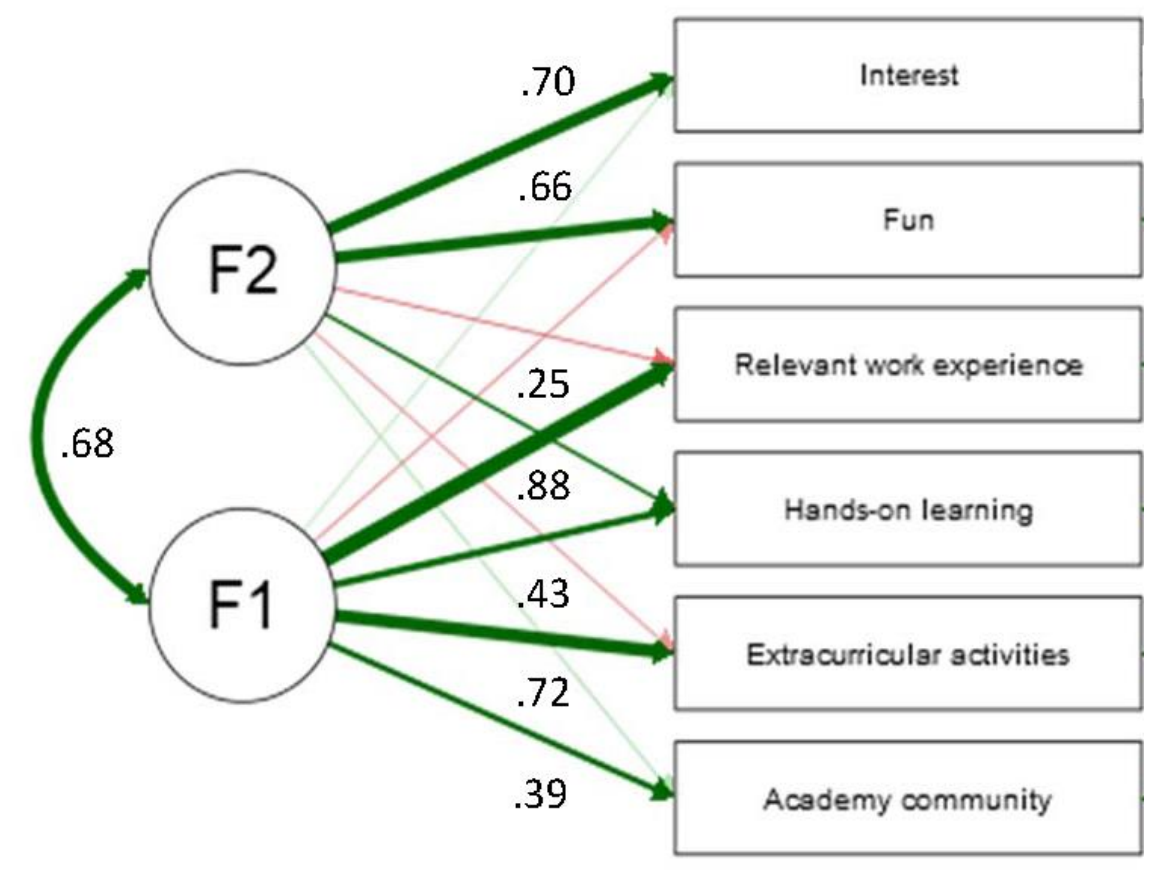

Figure 2. Path diagram representing best fit two factor model using top six items from survey questions 9 and $10(\mathrm{~N}=401)$. 
A Pareto analysis was conducted on the discrete data responses to survey Question 8 to identify the most relevant responses for how they learned about the academies (Figure 3). Pareto analysis allows for the selection of a limited number of responses that produce $80 \%$ of the overall effect. This survey question did not require the students to rank the importance of each selection, therefore a Pareto analysis was deemed more appropriate than a factor analysis to categorize factors into larger groups. The analysis indicated that Counselor was the most frequent response from all students, followed by Parents, Teachers, Other Students, Catalog, Website, and Brochure.

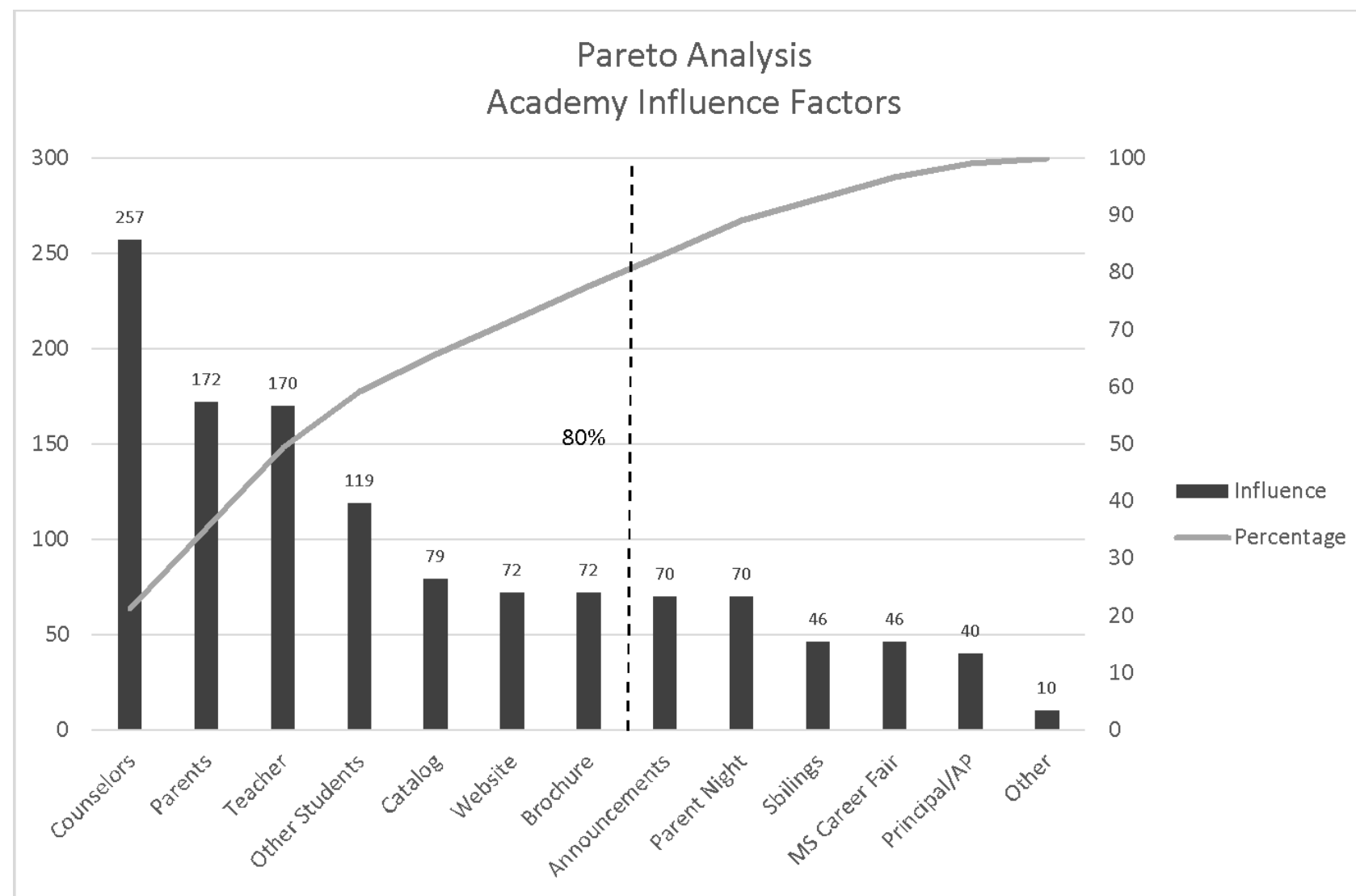

Figure 3. Pareto analysis, academy influence factors. Factors reported by all academy students as informing them of the career academies.

Research question 2. To address the second research question regarding the reasons non-academy high school students selected for why they did not apply for career academy 
programs, a Pareto analysis was conducted on responses to survey question 6, with the reasons of Did Not Know, Not Interested, and Missed Deadline providing 80\% of the responses as shown in Figure 4. A paired two-sample $t$-test was conducted at the onset of analysis to compare male and female means for group composite scores for the 22 items included in survey questions 8,9 , and 10 for data congruency. There was a significant difference between male and female responses $t(21)=1.91, p=0.035$. Several independent sample $t$-tests were then conducted on just the influence factor scores (responses to survey question 8 , How did you learn about the career academy?) to determine whether there were between-sex differences in the survey responses. Independent sample $t$-tests were conducted since $n$ was unequal for both groups. Null responses (respondents did not choose either male or female) were excluded from the analysis.

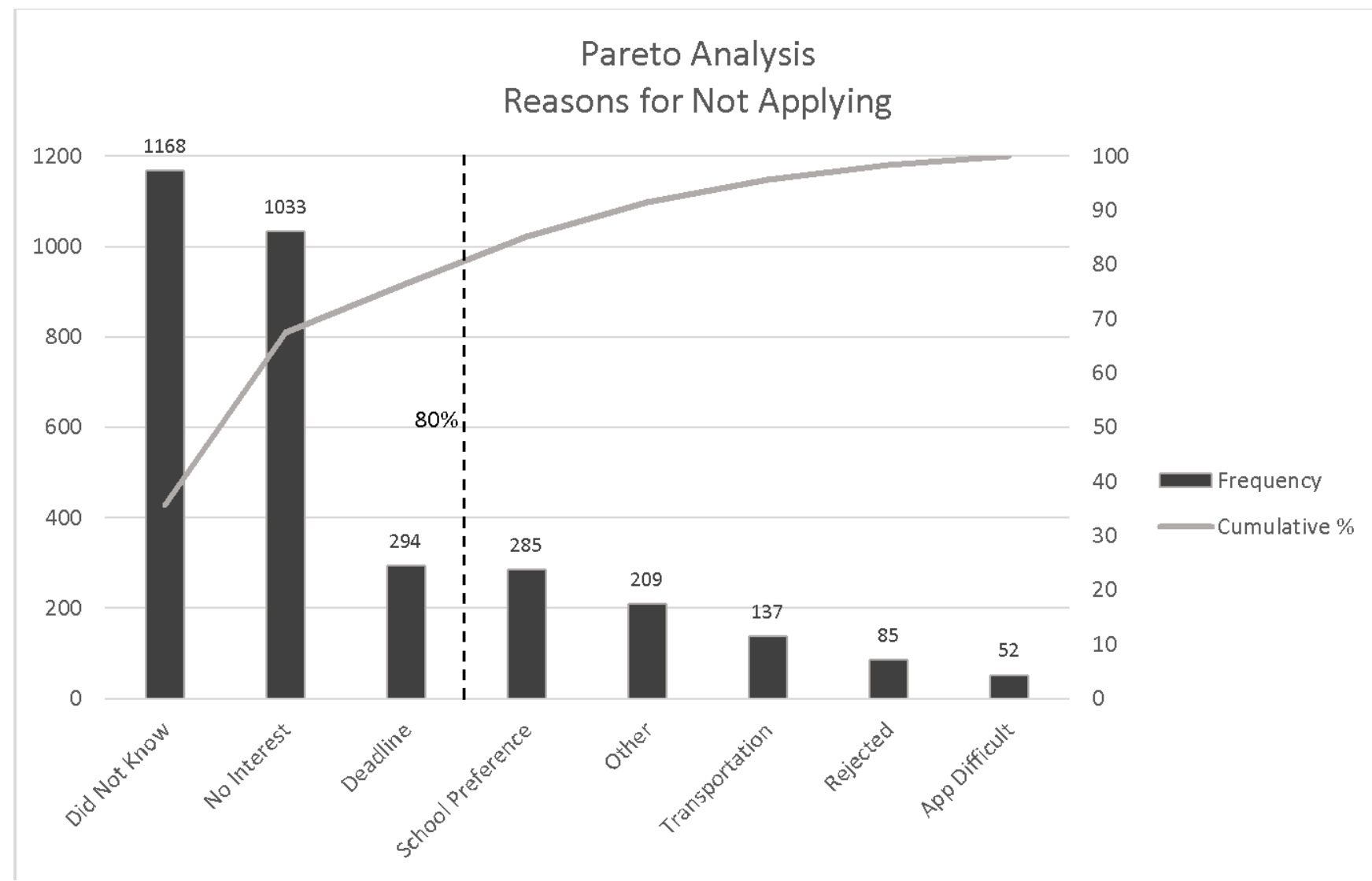

Figure 4. Pareto analysis, reasons for not applying. Reasons reported by non-academy students as why they did not apply. 
An independent-samples $t$-test was conducted to compare male and female means for composite scores for the 13 items from survey question 8; there was a significant difference between male $(n=175, M=26.22)$ and female $(n=219, M=30.18)$ responses $t(381)=1.91, p=$ 0.035. Further independent sample $t$-tests comparing male and female means were conducted on each of the top seven influencing factors as indicated by the Pareto analysis to determine which contributed to this between-sex difference. The only two factors in which there was a significant between-sex difference were Counselor $t(359)=3.80, p=0.000$ and Catalog $t(389)=1.66, p=$ 0.049, with females indicating these factors more often than males.

\section{Summary}

The purpose of this study was to assess the factors influencing students' decisions to enroll in career academy programs. To explore these factors, the results from an annual student climate survey administered by a school division were examined. This survey collected information from students who were currently enrolled in the division's career academies and from those who were not enrolled in current career academies. The information collected was student demographics, participation in current career academies, potential reasons for not enrolling in current career academies, how students learned about academies, why they applied for academies, and their experiences with the academies. A total of 3,258 responses were collected by the school division and shared with the researcher. After data cleaning there were 2,822 records for analysis. The data did not include any identifying information.

The data were analyzed with relationship to the research questions. Survey Questions 5 through 10 were related to career academies, with the exception of Question 7. Survey Question 5 asked the students if they were enrolled in a career academy, and directed students to the appropriate survey questions based on their response. If a student indicated they were enrolled in 
a career academy, they were directed to Questions 8, 9, and 10. Responses to survey Questions 8, 9, and 10 were used to address Research Question 1. If a student indicated they were not enrolled in a career academy, they were directed to Question 6. Responses from Question 6 were used to address Research Question 2.

Chapter V will summarize the research study and discuss the findings from this study. This chapter will also discuss conclusions based on the findings and make recommendations for future program planning and research based on the findings of this study. 


\section{CHAPTER V}

\section{SUMMARY, CONCLUSIONS, AND RECOMMENDATIONS}

This study examined the factors influencing students' decisions to enroll or not to enroll in a career academy program. This chapter summarizes the findings from this study and presents conclusions based on these findings. Finally, this chapter will make recommendations for future studies related to this topic.

\section{Summary}

As we move into and prepare to compete in the ever-changing global economy, policymakers, business and industry, as well as parents and students are discussing the challenges facing our schools (National Conference of State Legislators, 2018). Compared to other countries, the United States has one of the highest high school dropout rates and also faces poor college completion rates (U.S. Department of Education, 2017). While school reform efforts have been taking place for decades, many would argue that there have not been significant changes in the educational institution (Christensen, Aaron, \& Clark, 2005). Reforms are now focusing on excellent instruction, high standards for all, improved assessments, databased decision-making, and improved technology in schools (U.S. Department of Education, 2017). Career and technical education has been one focus of education reform, enabling students to learn relevant skills and knowledge that can help prepare them to be competitive in future career fields (Schwartz, 2016). An important emphasis is being placed on integrating these technical skills with academic subject areas to help close the gap for students (Loera, Nakamoto, Oh, \& Rueda, 2013). The career academy model is one type of program that focuses on this integration. 
Career academies are small learning communities focused on a specific career area. The goal of these programs is to help students learn their core academic material through the lens of a career field they may be interested in pursuing. Students in a career academy program are part of a cohort of students and teachers who work together to support each other. Students focus on curricula that prepares them for postsecondary education and entrance into a career in the related fields, and they work directly with business and industry partners to receive direct experience in those career fields (Stern et al., 2010). Research around career academies has found increased graduation rates, improved attendance, improved school climate, and higher sustained earnings after graduation (Kemple \& Scott-Clayton, 2004; Kemple \& Snipes, 2000; Kemple \& Wilbur, 2008; Stern et al., 2010). However, factors for enrolling or not enrolling in these types of programs have not been investigated. These factors for enrolling are important for program recruitment and retention, since interest in the career field can be important to student success in the program.

The purpose of this study was to assess the factors influencing students' decisions to enroll in career academy programs. The research questions addressed in this study were as follows:

$\mathrm{RQ}_{1}$ : What factors influence students to apply for career academy programs? $\mathrm{RQ}_{2}$ : What reasons do students have for choosing not to enroll in a career academy? This study used existing data collected by an urban school division. There were several limitations to this study. The study is limited to analyzing the factors influencing the students' decisions to enroll in the career academy program. Second, the study was limited to the comprehensive high schools within this school division. The findings from this study may or may not be generalized to other school divisions. When the data were collected, the school 
division had career academy programs at each high school in various stages of implementation. Students enrolled in these programs had a varying knowledge base of the program. Finally, all of the identified Career Clusters were not represented in the school division's academies.

The sample for this study included ninth through twelfth grade students enrolled in comprehensive high schools in an urban school division. This study used data from an existing instrument developed by the school division. The school division is not identified in this study and there was no student identifying information shared with the researcher. There were 3,258 responses from high school students enrolled in comprehensive high schools within the school division. Responses from students in alternative programs and surveys with no answer to the questions asking them about their academy enrollment were eliminated resulting in a sample of 2,421 students $(n=2,822)$. Students identified their current enrollment in a career academy program when they started the survey and the differentiated logic function within the instrument directed the students to the specific questions relating to their decision to enroll or not to enroll in the career academies. The responses were divided based on career academy enrollment with 401 students currently enrolled in a career academy and 2,421 students not enrolled in a career academy.

The school division launched the survey in December of 2016 to all students enrolled through their student email address. Students were asked questions on a variety of topics, with one section focused on career academies. Questions not related to career academies were not shared with the researcher. Survey Questions 8, 9, and 10 asked the students currently enrolled in a career academy how they learned about the program, why they applied for the program, and the importance of specific features of the career academy. The responses to these questions were used to address Research Question 1. Students who were not currently enrolled in a career 
academy were directed to survey Question 6, which asked the students why they did not apply for a career academy. Survey Question 6 was used to address Research Question 2. To address the research questions, descriptive statistics, t-tests, an exploratory factor analysis, and a Pareto analysis were conducted.

\section{Conclusions}

Conclusions for this study were drawn from the analysis as they related to each of the research questions. The first research question examined the reasons students had for entering a career academy. Survey Questions 9 and 10 were combined due to low internal consistency for the questions individually. The questions addressed the same concept of why the students wanted to be in the career academy. The factor analysis resulted in six reasons students gave for entering a career academy, including hands-on learning in the context of career interest, work experience outside of school related to what is being learned, attending activities and events related to the academy, interest in the career field, the idea that the academy would be fun, and being in classes with other academy students. Interestingly, the reasons of college applications, school choice, and parental influence had less of an effect.

While it is surprising that college applications and attending the school of their choice did not have a large impact on the decision to attend a career academy, the most surprising was parental influence. It has been found that parental influence has a significant influence on student success in school (Jeynes, 2012), and that parental influence has a significant effect on major and career choice (Keillor, Bush, \& Bush, 1995). One explanation may be the indirect nature of the parental influence and communication of parental expectations. Students may be influenced by their parents and not recognize this factor. A second explanation could be the setting in which students make course selections. While parents are invited to be part of the 
course selection process, most students receive information about course options directly from their counselors and without their parents present.

The factor analysis resulted in six reasons for entering the academy being sorted into factors. Factor one focused on the career academy experience with relevant work experience, hands-on learning, extracurricular activities, and the community that is built through the academy model. These features are important to students and should be the focus of developing future academies, building the current academies, and recruiting future students, teachers, and community partners. Factor two focused on student attitudes of interest in the career field and having fun through their high school career academy experience. These two items are also important to students and could be secondary influences during recruitment.

The two main factors of the career academy experience and interest in the career field are consistent with the goals of the career academy program. The main goals of the career academy are to create a small learning community, combine academic curricula with a career theme the student is interested in pursuing, and to provide experiences for students to receive direct experience in their chosen field of study (College \& Career Academy Support Network, 2012). Hands-on learning had the highest mean in the survey results for questions focused on the best features of and reasons for choosing the career academy. This type of learning is found to have positive effects on student interest (Holstermann, Grube, \& Bogeholz, 2010), and should continue to be incorporated into classrooms both in and out of academy programs to encourage student success. The amount of students indicating hands-on learning as a factor for their career academy selection is an indication that todays' students are looking for more ways to engage and make connections in their high school education (Taylor \& Parsons, 2011). This can be 
accomplished through the career academy model with the integration of career concepts with academic course work, which provides relevance for students (Medder \& Suddreth, 2012).

Survey Question 8 focused on how students learned about career academies. Students were asked to check all that applied to them in their response to this question. A Pareto analysis was used to examine the responses allowing for the selection of a limited number of responses that produced $80 \%$ of the overall effect. This analysis indicated that the school counselor had the greatest influence on informing students of the career academies. Significant responses also included parents, teachers, other students, the course catalog, the school division's website, and the career academy brochure. It is important to note that parent night events and middle school career fairs did not have as high of an influence which should be weighed with the amount of time and money spent on these events for future recruitment. The school counselor is not always the person students' indicate as having the most influence on decisions, however in this program counseling offices are where students picked up academy information and application packages. The school counselors were also the leads for recruiting at most academies and the counselors represented the academies at most of the recruitment events. Students may have actually learned about the academy at a career fair or parent night, but identified the counselor as the person who told them about the academy because the counselor was often the person at the table talking about benefits of the academy.

The second research question examined reasons students chose not to apply for the career academies. A Pareto analysis was also conducted to examine the responses to survey Question 6. Students indicated that not knowing about the academies, not being interested in the academies, and missing the application deadline produced $80 \%$ of the overall effect. Awareness is still the most important factor in recruiting future academy students. Increasing counselors' 
awareness of the career academies may aide in student awareness and academy recruitment. Each school may have had one counselor who lead recruitment efforts and focused on the academy students, but the remaining four-six counselors may not have had a strong understanding of the academy concept. It is also recommended that marketing efforts be increased and information sent directly to students and parents, along with sending information through counseling offices. Efforts can be made through sending information home with students, mailing information home, using parent and student email accounts, and u sing social media. Business partners may also prove to be valuable in assisting with marketing efforts and should be tapped into as a resource. Once again, the school preference was not one of the most influential factors. Also of note is transportation not being an influential factor. These two items have been assumed by school personnel to be a problem for students. However responses to the survey indicate that they are not as influential as anticipated.

Communication and awareness of available programs are often found to be challenges in recruitment and retention. When communicating with multiple stakeholders a clear plan must be in place and efforts must be made to communicate multiple times in multiple ways. Although the career academy information was communicated frequently and through a variety of media, many stakeholders were still seemingly unaware of the programs available and/or the process to apply for the programs. This indicates a need to vary communication based on the individual stakeholder, and to continue to educate the faculty and staff members who interact with students most. A variety of media can include, but are not limited to, presentations with stakeholder groups, social media and an online presence, individual meetings with various stakeholders, and printed materials. Faculty and staff members are also able to build relationships with students, 
which can enable staff members to help students overcome challenges and make decisions that will most benefit them in their future (Taylor \& Parsons, 2011).

\section{Recommendations}

The following recommendations for researchers and practitioners are based on the findings and conclusions of this study.

1. This study focused on the influential factors of student enrollment at the beginning of the career academy program. The study could be expanded in the school division participating in the study along with additional school divisions to incorporate influential factors from students in all grade levels to investigate changes in student perceptions as they move through high school. The study should also be expanded to include faculty and staff members who are involved with career academy programs to learn perceptions of the impact these programs have on student success.

2. The school division has continued to implement career academy programs for high school students. This survey should be continued each school year to collect data from additional students and allow the school division the opportunity to gain information that can influence programming. The survey should be expanded to include the importance of each of the factors the students select as influences in their decision-making process instead of checking the boxes for all that apply. The survey should also allow students to rank order the influences in their decision-making process. Further, it is recommended that additional questions, along with openended questions, be added to the overall survey to build strength for future research.

3. Longitudinal research should be conducted to determine the influence the career academy program has on student success in high school, postsecondary choices, and career decisions. 
This research should also include the impact of the career academy programs on students transferring into the school division and on students who transfer out of the school division prior to graduation. Collecting and analyzing this information would provide a valuable perspective for K-12 school divisions to consider when discussing high school reform.

4. While this study did consider several demographic factors, including sex and age, it could be expanded to include additional factors. These factors may include race, socio-economic status, diploma type, GPA, participation in athletics, school reputation, student attendance, and behavior. These factors may or may not be found to influence student decision in enrolling in these programs. The results from this expanded research could have further implications for program development and support. Additionally, research could be conducted to determine which types of recruiting methods have the most impact on various groups based on demographic factors. This information would lead to further development of recruitment and retention strategies. 


\section{REFERENCES}

ACT. (2005) Career planning: Students need help starting early and staying focused. Issues in College Readiness. Iowa City, IA. (ED510441)

Advance CTE. (2017). Career and technical education. Silver Spring, MD. Retrieved from https://www.careertech.org/CTE

Alfred, C., Stone, J., Aragon, S. R., Hansen, D. M., Zirkle, C., Connors, J. ...Woo, H. (2007).

Looking inside the black box: The value added by career and technical student organizations to students' high school experience. Atlanta, GA: National Research Center for Career and Technical Education.

Alivernini, F., \& Lucidi, F. (2011). Relationship between social context, self-efficacy, motivation, academic achievement, and intention to drop out of high school: A longitudinal study. Journal of Educational Research, 104(4), 2410252. doi:10.1080/00220671003728062

Association for Career and Technical Education. (2016). What is CTE? Alexandria, VA: ACTE. Retrieved from https://www.acteonline.org/cte/\#.WRInwfkrKUk

Association for Career and Technical Education. (2017). Career Clusters. Alexandria, VA: ACTE. Retrieved from https://www.acteonline.org/general.aspx?id=8644\#. WRHeQfnyuUk

Beggs, J. M., Bantham, J. H., \& Taylor, S. (2008). Distinguishing the factors influencing college students' choice of major. College Student Journal, 42(2), 381-394.

Brand, B., Valent, A., \& Browning, A. (2013). How career and technical education can help students be college and career ready: A primer. Washington, DC: College and Career Readiness \& Success Center at American Institutes for Research. 
Brockmann, M., Clarke, L., \& Winch, C. (2008). Knowledge, skills, competencies: European divergences in vocational education and training (VET) - the English, German and Dutch cases. Oxford Review of Education, 34(5), 547-567. Doi:10.1080/03054980701782098

Brustein, M. (2006). Perkins Act of 2006: The official guide. Alexandria, VA: The Association of Career and Technical Education.

Carl D. Perkins Career and Technical Education Improvement Act of 2006. Pub. L. No. 109-270, 120 Stat. 683 (2006).

Carnevale, A. P., Smith, N., \& Strohl, J. (2010). Help wanted: Projections of jobs and education requirements through 2018. Washington, DC: Georgetown University Center on Education and the Workforce.

Castellano, M., Stringfield, S., \& Stone, J. I. (2003). Secondary career and technical education and comprehensive school reform: Implications for research and practice. Review of Educational Research, 73(2), 231-272.

Chmielewski, A. K. (2014). An international comparison of achievement inequality in withinand between-school tracking systems. American Journal of Education, 120(3), 293-324.

Christensen, C., Aaron, S., \& Clark, W. (2005). Can schools improve? Phi Delta Kappan, 86(7).

Chung, Y. B., Loeb, J. W., \& Gonzo, S. T. (1996). Factors predicting the educational and career aspirations of black college freshmen. Journal of Career Development, 23(2), 127-135.

College and Career Academy Support Network (2012). College and career academies: An overview. Retrieved from https://casn.berkeley.edu/resources.php?r=249

College and Career Academy Support Network (2017). Linked components of college and career academies. Retrieved from https://casn.berkeley.edu/resources.php?r=249 
Costello, A. B., \& Osborne, J. (2005). Best practices in exploratory factor analysis: Four recommendations for getting the most from your analysis. Practical Assessment Research \& Evaluation, 10(7). Retrieved from http://pareonline.net/getvn.asp?v=10\&n=7

Cotner, H., Folkers, D., Mills, D., Whitney, M., Symonds, W. C., Bray, J. ... Hinckley, R. (2012). The Career Pathways effect: Linking education and economic prosperity. Waco, TX: CORD Communications.

Cotton, K. (2001). New small learning communities: Findings from recent literature. Portland, OR: Northwest Regional Educational Lab. (ED459539)

Davis, M. H., \& McPartland, J. M. (2012). High school reform and student engagement. In S. L. Christensen, A. L. Reschly, \& Wylie, C. (Eds.), Handbooks of research on student engagement (pp. 515-539). New York, NY: Springer.

Deci, E. L., \& Ryan, R. M. (2000). Self-determination theory and the facilitation of intrinsic motivation, social development, and well-being. American Psychologist, 55(1), 68-78.

Dixon, M. L., Cotner, B. A., Wilson, T. N. C., \& Borman, K. M. (2011). Implementing career academies in Florida: A case study approach to understanding successes and obstacles. Career and Technical Education Research, 36(3), 207-227. doi:10.5328/cter36.3.207

Dougherty, S. M. (2016). Career and technical education in high school: Does it improve student outcomes? Washington, DC: Thomas B. Fordham Institute.

European Commission. (2013). Work-based learning in Europe: Practices and policy pointers. Retrieved from http://ec.europa.eu/education/policy/vocational-policy/doc/alliance/workbased-learning-in-europe_en.pdf 
Frady, W. P. (2005). A study of high school students' career interest inventories and their relationships to students' completion of occupational programs. Retrieved from ProQuest Dissertations \& Theses Global database. (305007796).

George, P. S., \& Lounsbury, J. H. (2000). Making big schools feel small: Multiage grouping, looping, and schools-within-a-school. Westerville, OH: National Middle School Association.

Gordon, H. R. D. (2014). The history and growth of career and technical education in America. Prospect Heights, IL: Waveland Press.

Green, K. (2012). Common career and technical core: Common standards, common vision for CTE. Techniques: Connecting Education and Careers, 87(6), 44-47.

Grolnick, W. S., Ryan, R. M., \& Deci, E. L. (1991). The inner resources for school performance: Motivational mediators of children's perceptions of their parents. Journal of Educational Psychology, 53, 508-517.

Harrington, T., \& Long, J. (2013). The history of interest inventories and career assessments in career counseling. The Career Development Quarterly, 61(1), 83-92.

Heidemann, W. (2000). Lifelong learning and employability: Is the European model of vocational training in crisis? European Trade Union Institution: Brussels.

Hidi, S., \& Harackiewicz, J. M. (2000). Motivating the academically unmotivated: A critical issue for the $21^{\text {st }}$ century. Review of Educational Research, 70, 151-179.

Hoachlander, G., \& Steinhauser, C. J. (2015). Career and technical education must be integrated with academic coursework. Oakland, CA: EdSource.

Holstermann, N., Grube, D., \& Bogeholz, S. (2010). Hands-on activities and their influence on students' interest. Research in Science Education, 40(5), 743-757. 
Hoye, J. D., \& Stern, D. (2008). The career academy story. Education Week, 28(3), 24-26.

Hoyt, K. B. (1984). Helping parents understand career education. Journal of Career Education, $10,216-224$.

Hull, D. (2003). Redefining CTE: Seizing a unique opportunity to help the 'neglected majority' become world-class students, workers and citizens. Techniques: Connecting Education \& Career, 78(5), 30.

Hyslop, A. (2009). The role of career academies in education improvement. Techniques: Connecting Education and Careers, 84(6), 32-35.

Hyslop-Margison, E. J. (2000). An assessment of the historical arguments in vocational education reform. Journal of Career and Technical Education, 17(1).

Jankowski, N. A., Kirby, C. L., Bragg, D. D., Taylor, J. L., \& Oertle, K. M. (2009). Illinois' Career Cluster model. Urbana-Champaign, IL: OCCRL, University of Illinois at UrbanaChampaign.

Jeynes, W. (2012). A meta-analysis of the efficacy of different types of parental involvement programs for urban students. Urban Education, 47(4), 706-742.

Kazis, R. (2005). Remaking career and technical education for the $21^{\text {st }}$ century: What role for high school programs? Double the Numbers: A Jobs for the Future Initiative. Washington, DC: The Aspen Institute.

Keillor, B. D., Bush, R. P., \& Bush, A. J. (1995). Marketing-based strategies for recruiting business students in the next century. Marketing Education Review, 5(3), 69-79.

Kemple, J. J. (1997) Career academies. Communities of support for students and teachers: Emerging findings from a 10-site evaluation. New York, NY: Manpower Demonstration Research Corporation. 
Kemple, J. J. (2001). Career academies: Impacts on students' initial transitions to postsecondary education and employment. New York, NY: Manpower Demonstration Research Corporation.

Kemple, J. J., Poglinco, S. M., \& Snipes, J. C. (1999). Career academies: Building career awareness and work-based learning activities through employer partnerships. New York, NY: Manpower Demonstration Research Corporation.

Kemple, J. J., \& Rock, J. L. (1996). Career academies: Early implementation lessons from a 10 site evaluation. New York, NY: Manpower Demonstration Research Corporation.

Kemple, J. J., \& Scott-Clayton, J. (2004). Career academies, Impact on students' initial transitions to postsecondary education and employment. New York, NY: Manpower Demonstration Research Corporation.

Kemple, J. J., \& Snipes, J. C. (2000). Career academies: Impact on students' engagement and performance in high school. New York, NY: Manpower Demonstration Research Corporation.

Kemple, J. J., \& Wilbur, S. (2008). Long-term impacts on labor market outcomes, educational attainment, and transitions to adulthood. New York, NY: Manpower Demonstration Research Corporation.

Kolenikov, S., \& Angeles, G. (2004). The use of discrete data in PCA: Theory, simulations, and applications to socioeconomic indices. Chapel Hill, NC: Measure Evaluation.

Kuo, V. (2010). Transforming American high schools: Possibilities for the next phase of high school reform. Peabody Journal of Education, 85(3), 398-401. doi:10.1080/0161956X.2010.491709 
Lawrence, A. A., \& Vimala, A. (2013). Self-concept and achievement motivation of high school students. Conflux Journal of Education, 1(1), 141-205.

Lawrence, D. (1996). Enhancing self-esteem in the classroom. London, UK: Paul Chapman.

Lee, V. E., \& Smith, J. B. (2000). School size in Chicago elementary schools: Effects on teachers' attitudes and students' achievement. American Educational Research Journal, 37(1), 3-31.

Leppel, K., Williams, M. L., \& Waldauer, C. (2001). The impact of parental occupation and socioeconomic status on choice of college major. Journal of Family and Economic Issues, 22(4), 373-394.

Levine, K. A., \& Sutherland, D. (2013). History repeats itself: Parental involvement in children's career exploration. Canadian Journal of Counseling and Psychotherapy, 47(2), 239-255.

Lewis, A. C. (1999). Direct from Washington: Career academies. Tech Directions, 59(1). 6.

Lewis, M. V., \& Pearson, D. (2007). Sustaining the impact: A follow-up of the teachers who participated in the math-in-CTE study. Atlanta, GA: National Research Center for Career and Technical Education.

Library of Congress. (2017). Primary documents in American history: Morrill Act. Washington, DC. Retrieved from https://www.loc.gov/rr/program/bib/ourdocs/Morrill.html

Loera, G., Nakamoto, J., Oh, Y. J., \& Rueda, R. (2013). Factors that promote motivation and academic engagement in a career and technical education context. Career and Technical Education Research, 38(3), 173-190. doi:10.5328/cter38.3.173

Lozano, L. M., Garcia-Cueto, E., \& Muniz, J. (2008). Effect of the number of response categories on the reliability and validity of rating scales. European Journal of Research Methods for the Behavioral and Social Sciences, 4, 73-79. doi: 10.1027/1614-2241.4.2.73 
Maxwell, N. L. (2001). Step to college: Moving from the high school career academy through the four-year university. Evaluation Review, 25(6), 619-654.

Maxwell, N. L., \& Rubin, V. (2001). Career academy programs in California: Outcomes and implementation. CPRC Report. Oakland, CA: University of California, California Policy Research Center.

Meeder, H., \& Suddreth, T. (2012). Common core state standards \& career and technical education: Bridging the divide between college and career readiness. Washington, DC: Achieve.

National Center on Education and the Economy. (2008). Tough choices or tough times: The report of the new commission on the skills of the American workforce (Rev. ed.). San Francisco, CA: Jossey-Bass.

National Conference of State Legislators. (2018). High Schools. Washington, DC.

National Research Council Institute of Medicine. (2013). Engaging schools: Fostering high school students' motivation to learn. Washington, DC: National Academies Press.

Nunnery, J. (1998). Reform ideology and the locus of development problem in educational restructuring: Enduring lessons from studies on educational innovations. Education and Urban Society, 30, 277-295.

Office of Vocational and Adult Education. (2012). Investing in America's future: A blueprint for transforming career and technical education. Washington, DC.

Orr, M. T. (2006). Career academies as a professionally engaging and supportive teaching experience. Education and Urban Society, 37(4), 453-489.

Orr, M. T., Bailey, T., Hughes, K. L., Kienzl, G. S., \& Karp, M. M. (2004). The national academy foundation's career academies: Shaping postsecondary transitions. In D. 
Neumark (Ed.), Improving school to work transitions (pp. 169-173). New York, NY: Russell Sage Foundation.

Orr, M. T., Hughes, K. L., \& Karp, M. M. (2002). A quality transition: Career academy seniors' improved preparedness and alumni career and educational success: The National Academy Foundation story. Paper presented at the annual meeting of the American Educational Research Association, New Orleans, LA.

Partnership for $21^{\text {st }}$ Century Schools (2010). Up to the challenge: The role of career and technical education and $21^{\text {st }}$ century skills in college and career readiness. Retrieved from https://files-eric-ed-gov.proxy.lib.odu.edu/fulltext/ED519335.pdf

Pautler, A. J. (1999). Workforce education: Issues for the new century. Ann Arbor, MI: Prakken Publications.

Pearson, D., Young, B. R., \& Richardson, G. B. (2013). Exploring the technical expression of academic knowledge: The science-in-CTE pilot study. Journal of Agricultural Education, $54(4), 162-179$.

Raywid, M. A. (1996). Taking stock: The movement to create mini-schools, schools-withinschools, and separate small schools. Urban Diversity Series No. 108. New York, NY: ERIC Clearinghouse on Urban Education, \& Center on Organization and Restructuring of Schools.

Reese, S. (2011). Creating the leaders of tomorrow today. Techniques, 86(5), 16-21.

Reeve, J. (2002). Self-determination theory applied to educational settings. Washington, DC: American Psychological Association. 
Roberson, Robin. (2013). Helping students find relevance. Psychology Teacher Network. Washington, DC: American Psychological Association. Retrieved from http://www.apa.org/ed/precollege/ptn/2013/09/students-relevance.aspx

Rojewski, J. W., Lee, I., \& Gemici, S. (2010). Using propensity score matching to determine the efficacy of secondary career academies in raising educational aspirations. Career and Technical Education Research, 35(1), 3-27.

Rojewski, J. W., \& National Dissemination Center for Career and Technical Education, C. O. (2002). Preparing the workforce of tomorrow: A conceptual framework for career and technical education.

School-to-Work Opportunities Act of 1994. Conference report to accompany H. R. 2884 House of Representatives, 103D Congress, 2d Session (1994).

Schwartz, R. (2016). Memo: Career and technical education. Washington, DC: Brookings Institution.

Smith, T. J. (2008). Striking the balance: Career academies combine academic rigor and workplace relevance. Washington, DC: American Institutes for Research, National High School Center.

Stern, D. (2001). Career academies and high-school reform before, during, and after the schoolto-work movement. (Report No. EDO-CE-084-610). Washington, DC: Office of Educational Research and Improvement. (ED 474217).

Stern, D. (2015). What constitutes an effective career academy? School Administrator, 72(4), 2829. 
Stern, D., Dayton, C. Lenz, R., \& Tidyman, S. (2002). Implementing career academies schoolwide: 2001-2002 developments, promising practices. Berkeley, CA: California University Berkeley Career Academy Support Network.

Stern, D., Dayton, C, \& Raby, M. (2000). Career academies: Building blocks for reconstructing American high schools. Berkeley, CA: University of California, Berkeley, Career Academy Support Network.

Stern, D., Dayton, C., \& Raby, M. (2010). Career academies: A proven strategy to prepare high school students for college and careers. Berkeley, CA: University of California, Berkeley, Career Academy Support Network.

Stern, D., \& Hoachlander, G. (2011). Evidence on career academies and linked learning. Retrieved from https://casn.berkeley.edu/resources_files/Evidence_acads_LL_11.21.1111 -11-21-03-19-06.pdf

Stone, J. R. III., Alfred, C., Pearson, D., Lewis, M. V., \& Jensen, S. (2006). Building academic skills in context: Testing the value of enhanced math learning in CTE. Minneapolis, MN: National Research Center for Career and Technical Education.

Stone, J. R. III. \& Lewis, M. V. (2012). College and career ready for the $21^{\text {st }}$ century: Making high school matter. New York, NY: Teacher's College Press.

Symonds, W. C., Schwartz, R. B., \& Ferguson, R. (2011). Pathways to prosperity: Meeting the challenge of preparing young Americans for the $21^{\text {st }}$ century. Cambridge, MA: Harvard Graduate School of Education.

Taylor, L., \& Parsons, J. (2011). Improving student engagement. Current Issues in Education, 14(1). 
Thompson, J. F. (1973). Foundations of vocational education. Englewood Cliffs, NJ: PrenticeHall.

Threeton, M. D. (2007). The Carl D Perkins Career and Technical Education Act of 2006 and the roles and responsibilities of CTE teachers and faculty members. Journal of Industrial Teacher Education, 44(1), 66-82.

Torpey, E. (2015). Clusters, pathways, and BLS: Connecting career information. Washington, DC: Bureau of Labor Statistics.

Tyack, D. (1974). The one best system: A history of American urban education. Cambridge, MA: Harvard University Press.

United States Department of Education. (2008). A nation accountable: Twenty-five years after “A nation at risk”. Washington, DC. (ED502924).

United States Department of Education. (2017). Progress in our schools. Washington, DC.

Vallerand, R. J., \& Ratelle, C. F. (2002). Intrinsic and extrinsic motivation: A hierarchical model. Handbook of Self-Determination Research, 128, 37-63.

Virginia Department of Education. (2012). APG users guide. Retrieved from http://www.cteresources.org/apg/introduction

Weiss, C. (1998). Evaluation (2 ${ }^{\text {nd }}$ ed.). Saddle River, NJ: Prentice Hall.

Werfhorst, H. G. (2014). Changing societies and four tasks of schooling: Challenges for strongly differentiated educational systems. International Review of Education, 60(1), 123-144.

Williams, R. \& Stockdale, S. (2004). Classroom motivation strategies for prospective teachers. The Teacher Educator, 39, 212-230.

Wilson, M., \& Gerber, L. E. (2008). How generational theory can improve teaching: Strategies for working with the "Millennials". Currents in Teaching and Learning, 1(1), 29-44/ 
Wonacott. M. E. (2001). Career Clusters. The highlight zone: Research @ work. Columbus, OH: National Dissemination Center for Career and Technical Education.

Wonacott, M. E. (2003). History and evolution of vocational education and career-technical education. A compilation. Columbus, $\mathrm{OH}$ : Center on Education and Training for Employment.

Wormington, S. V., Corpus, J., \& Anderson, K. G. (2012). A person-centered investigation of academic motivation and its correlates in high school. Learning and Individual Differences, 22(4), 429-438. doi: 10.1016/j.lindif.2012.03.004 


\section{APPENDIX A \\ 2016-2017 Student Climate Survey}

\section{Welcome}

As a student, you have important information to tell us about your school. We want to hear from you. Please think about your experience at school this year as you read each of the following questions. Your answers to the survey will help us improve education for all students.

(* indicates required questions)

* 1. Please select your school from the drop-down list below.

School A

School B

School C

School D

(School names removed for confidentially)

* 2. Please select your current grade level.

$9^{\text {th }}$ grade

$10^{\text {th }}$ grade

$11^{\text {th }}$ grade

$12^{\text {th }}$ grade

\section{Teaching and Learning}

* 3. Think about all of the classes you take as you answer the questions below.

\begin{tabular}{|c|c|c|c|c|c|}
\hline & Never & Rarely & Sometimes & Usually & Always \\
\hline My teachers tell me what I need to know to do well in school & O & O & O & O & O \\
\hline I am challenged by the work at school & O & O & O & O & O \\
\hline My grades are an accurate picture of what I learn in class & O & O & O & O & O \\
\hline $\begin{array}{l}\text { My teachers show me how our lessons relate to life outside of } \\
\text { school }\end{array}$ & O & O & O & O & O \\
\hline My teachers give me extra help when I need it & O & O & O & O & O \\
\hline My teachers tell me how well I do on my assignments and & O & $\mathrm{O}$ & $\mathrm{O}$ & 0 & 0 \\
\hline
\end{tabular}

4. Please tell us how your teachers can better help you to learn. 


\section{Career Academies}

* 5. Are you currently in a career academy?

- Academy A at School A

- Academy B at School B

- Academy $\mathrm{C}$ at School C

- Academy D at School D

- I am not in a career academy

\section{Career Academies - Why not?}

* 6. Why didn't you apply for a career academy (Check all that apply)

- I didn't know about the academies

- I'm not interested in those careers

- The application was too long/hard

- I missed the application deadline

- I did not have transportation to the program that interested me

- I did not want to leave my zoned high school to attend a different academy

- I applied, but was not accepted

○ Other (please specify) 


\section{Career Academies - What interests you?}

Each of the industry clusters below offers a wide variety of potential careers which often don't seem closely related; we have given a variety of example careers for each. If you do not see a particular career, please rate the industry cluster that is most closely related as "very interested".

* 7. What career fields would interest you for future academies?

Very interested Somewhat interested Not interested

\begin{tabular}{|c|c|c|c|}
\hline $\begin{array}{l}\text { HOSPITALITY \& TOURISM (Example careers: Chef, } \\
\text { Sports Manager, Travel Agent) }\end{array}$ & 0 & 0 & 0 \\
\hline $\begin{array}{l}\text { INFORMATION TECHNOLOGY (Example careers: } \\
\text { Video Game Development, Virtual Simulations, } \\
\text { Computer Programming, Cyber Security) }\end{array}$ & 0 & 0 & 0 \\
\hline
\end{tabular}

\begin{tabular}{|c|c|c|c|}
\hline $\begin{array}{l}\text { LAW \& PUBLIC SAFETY (Example careers: Police } \\
\text { Officer, Fire Fighter, EMT, Lawyer, Military) }\end{array}$ & 0 & 0 & 0 \\
\hline $\begin{array}{l}\text { TRANSPORTATION, DISTRIBUTION, \& } \\
\text { LOGIS TICS (Example careers: Civil Engineer, Customs } \\
\text { Inspector, Port Manager, Urban Planner) }\end{array}$ & 0 & 0 & 0 \\
\hline
\end{tabular}

\begin{tabular}{|c|c|c|c|}
\hline $\begin{array}{l}\text { EDUCATION \& HUMAN SERVICES (Example } \\
\text { careers: Teacher, Counselor, Community Service } \\
\text { Director, Social Worker, Psychologist) }\end{array}$ & 0 & 0 & O \\
\hline $\begin{array}{l}\text { ARTS \& ENTERTAINMENT (Example careers: Music } \\
\text { Production, Art Director, Publicist, Production } \\
\text { Manager) }\end{array}$ & 0 & 0 & O \\
\hline
\end{tabular}

\begin{tabular}{|c|c|c|c|}
\hline $\begin{array}{l}\text { ARCHITECTURE \& CONSTRUCTION (Example } \\
\text { careers: Architect, Interior Designer, Engineer, } \\
\text { Carpenter) }\end{array}$ & 0 & O & 0 \\
\hline $\begin{array}{l}\text { ENTREPRENEURSHIP \& BUSINESS (Example } \\
\text { careers: Small Business Owner, Marketing Director, } \\
\text { Advertising Manager, Accountant, Manager) }\end{array}$ & 0 & 0 & O \\
\hline
\end{tabular}

\begin{tabular}{|c|c|c|c|}
\hline $\begin{array}{l}\text { MANUFACTURING \& ENGINEERING (Example } \\
\text { careers: Machine Operator, Welder, Design Engineer, } \\
\text { Environmental Engineer, Electrical Engineer) }\end{array}$ & 0 & 0 & 0 \\
\hline $\begin{array}{l}\text { HEALTH SCIENCES (Example careers: Nurse } \\
\text { Practitioner, Therapist, Paramedic, Microbiologist, } \\
\text { Biomedical Engineer) }\end{array}$ & 0 & 0 & 0 \\
\hline
\end{tabular}




\section{Career Academies}

* 8. How did you learn about the career academy? (Choose all that apply)

- Parents

- Siblings

- Teachers

○ School Counselor

- Principal/Assistant Principal

- Other Students

- Middle School Career Fair

- Rising $8^{\text {th }}$ Grade Parent Night

- Website

- Course Offering Guide

- Announcements

- Brochures

O Other (Please specify)

* 9. Why did you apply for the career academy? (Rate the importance of each item)

Very important Somewhat important Slightly important Not important

$\begin{array}{lccc}\text { I am interested in this career field } & \text { O } & \text { O } & 0 \\ \begin{array}{l}\text { I wanted to go the school where the } \\ \text { academy is located }\end{array} & 0 & 0 & 0 \\ \text { My parents wanted me to apply } & 0 & 0 & 0 \\ \text { It will look good for college } & 0 & 0 & 0 \\ \text { I thought it would be fun } & 0 & 0 & 0\end{array}$


* 10. Career academy experiences should be different from traditional high school. How important are these features in your academy experience?

$$
\text { Very important Somewhat important Slightly important } \begin{gathered}
\text { I did not } \\
\text { experience this }
\end{gathered}
$$

\begin{tabular}{lllll}
$\begin{array}{l}\text { Being in classes with other academy } \\
\text { students }\end{array}$ & O & 0 & 0 & 0 \\
$\begin{array}{l}\text { Hands-on learning in the context of my } \\
\text { career interest }\end{array}$ & 0 & 0 & 0 & 0 \\
$\begin{array}{l}\text { Attending activities and event outside of } \\
\text { school related to the academy }\end{array}$ & 0 & 0 & 0 & 0 \\
$\begin{array}{l}\text { Work experience outside of school related } \\
\text { to what I am learning }\end{array}$ & 0 & 0 & 0 & 0 \\
Other (please specify) & & & \\
\hline
\end{tabular}

\section{Career Academies - Final Thoughts}

11. Please tell us anything else you think we need to know about Career Academies. 


\section{Safety \& Behavior}

* 12. My school provides a safe environment for teaching and learning.

- Strongly Disagree

- Disagree

- Agree

- Strongly Agree

13. Tell us more about Safety \& Behavior on the bus or at the bus stop.

\begin{tabular}{|c|c|c|c|}
\hline $\begin{array}{l}\text { Strongly } \\
\text { Disagree }\end{array}$ & Disagree & Agre & $\begin{array}{l}\text { Strongly } \\
\text { Agree }\end{array}$ \\
\hline
\end{tabular}

I feel safe while waiting at the bus stop

I feel safe when I am on my school bus
○

$\circ$

○

○
○

O
○

○
○

○

14. Tell us more about Safety \& Behavior at school.

\begin{tabular}{|c|c|c|c|c|}
\hline & $\begin{array}{l}\text { Strongly } \\
\text { Disagree }\end{array}$ & Disagree & Agree & Strongly Agree \\
\hline I feel safe at school & 0 & O & O & O \\
\hline I respect the teachers at this school & 0 & O & O & O \\
\hline Other students are friendly at this school & 0 & 0 & 0 & 0 \\
\hline Discipline is enforced fairly at this school & O & O & O & O \\
\hline $\begin{array}{l}\text { I have seen students threatened or bullied } \\
\text { at this school }\end{array}$ & $\mathrm{O}$ & $\mathrm{O}$ & $\mathrm{O}$ & $\mathrm{O}$ \\
\hline $\begin{array}{l}\text { I have been a target of bullying at this } \\
\text { school }\end{array}$ & O & O & O & O \\
\hline $\begin{array}{l}\text { I have seen alcohol and/or drugs at this } \\
\text { school }\end{array}$ & $\mathrm{O}$ & $\mathrm{O}$ & $\mathrm{O}$ & O \\
\hline I have seen gang activity at this school & O & O & O & O \\
\hline I have seen weapons in this school & 0 & 0 & 0 & 0 \\
\hline
\end{tabular}

15. How can we improve safety? 


\section{Care \& Support}

* 16 . The adults in my school are caring and supportive.

○ Strongly Disagree

- Disagree

- Agree

- Strongly Agree

\section{Tell us more about Student Support}

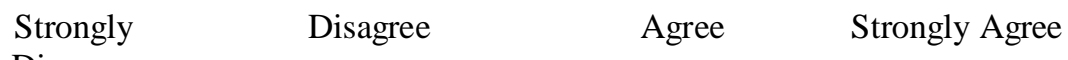

\begin{tabular}{|c|c|c|c|c|}
\hline \\
\hline My principal cares about me & 0 & O & O & O \\
\hline My assistant principal cares about me & $\mathrm{O}$ & O & O & $\mathrm{O}$ \\
\hline $\begin{array}{l}\text { I can talk to the principal or another } \\
\text { administrator when I have a problem at } \\
\text { school }\end{array}$ & $\mathrm{O}$ & $\mathrm{O}$ & O & $\mathrm{O}$ \\
\hline My teachers care about me & $\mathrm{O}$ & O & $\mathrm{O}$ & O \\
\hline $\begin{array}{l}\text { Teachers and staff treat students fairly } \\
\text { regardless of their backgrounds and } \\
\text { differences }\end{array}$ & $\mathrm{O}$ & $\mathrm{O}$ & $\mathrm{O}$ & $\mathrm{O}$ \\
\hline $\begin{array}{l}\text { I feel encouraged by my teachers to do the } \\
\text { best I can in school }\end{array}$ & $\mathrm{O}$ & $\mathrm{O}$ & $\mathrm{O}$ & $\mathrm{O}$ \\
\hline $\begin{array}{l}\text { There is a teacher, counselor or other staff } \\
\text { member at school I can talk to about } \\
\text { school problems }\end{array}$ & $\mathrm{O}$ & $\mathrm{O}$ & $\mathrm{O}$ & $\mathrm{O}$ \\
\hline $\begin{array}{l}\text { There is a teacher, counselor or other staff } \\
\text { member at school I can talk to about } \\
\text { personal problems }\end{array}$ & $\mathrm{O}$ & O & $\mathrm{O}$ & $\mathrm{O}$ \\
\hline
\end{tabular}

18. Please tell us how we can support you better at school. 


\section{Cultural Competence}

* 19. Students at this school are treated fairly regardless of their culture, disabilities, gender, race, religion, or sexual orientation.

- Strongly Disagree

- Disagree

- Agree

- Strongly Agree

- Don't Know

20. Students are this school are treated unfairly based on their (check all that apply):
- Culture
- Disabilities
○ Gender
- Race
○ Religion
- Sexual Orientation
O Other (please specify)

21. Is there anything else you'd like to tell us about the way students are treated at this school? 


\section{Parent Involvement}

* 22. My parent or another family member is involved in my education.

○ Strongly Disagree

- Disagree

- Agree

- Strongly Agree

23. Tell us more about Parent Involvement.

Never Rarely Sometimes Usually Always

\begin{tabular}{|c|c|c|c|c|c|}
\hline $\begin{array}{l}\text { My parents make sure I do my homework } \\
\text { every night }\end{array}$ & $\mathrm{O}$ & O & O & O & O \\
\hline My parents ask me about my day at school & O & $\mathrm{O}$ & O & O & $\mathrm{O}$ \\
\hline $\begin{array}{l}\text { My parents attend school activities with } \\
\text { me }\end{array}$ & $\mathrm{O}$ & O & O & O & O \\
\hline $\begin{array}{l}\text { My parents or another family member help } \\
\text { me with my homework if I ask }\end{array}$ & O & O & O & O & O \\
\hline My parents volunteer at school & O & O & O & O & O \\
\hline $\begin{array}{l}\text { My parents communicate with my teachers } \\
\text { about how I am doing in school }\end{array}$ & O & O & O & O & O \\
\hline
\end{tabular}

about how I am doing in school

24. Please share your thoughts about your parents' or family members' involvement at school. 


\section{Technology}

* 25. Technology is used at school to help me learn.

- Strongly disagree

$\circ$ Disagree

- Agree

- Strongly agree

26. Tell us more about Technology.

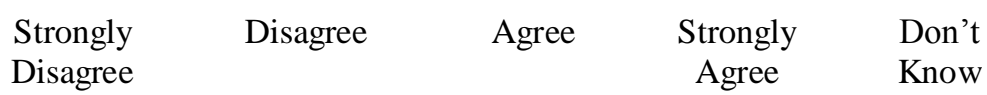

$\begin{array}{lccccc}\text { I have access to computers at school } & 0 & 0 & 0 & 0 & 0 \\ \begin{array}{l}\text { The computers available to me at school } \\ \text { are up-to-date }\end{array} & 0 & 0 & 0 & 0 & 0 \\ \begin{array}{l}\text { The computers and other technology at } \\ \text { school work when needed }\end{array} & 0 & 0 & 0 & 0 & 0\end{array}$

27. Please tell us how the computers and technology at school can better help you learn.

\section{Internet Access}

* 28. I have internet access at home to do my schoolwork.

- Yes

- No 


\section{School Cleanliness}

* 29. My school is clean.

- Strongly Disagree

- Disagree

- Agree

- Strongly Agree

30. Tell us more about School Cleanliness.

$\begin{array}{lcccc} & \begin{array}{c}\text { Strongly } \\ \text { Disagree }\end{array} & \text { Disagree } & \text { Agree } & \text { Strongly Agree } \\ \begin{array}{l}\text { The cafeteria in my school is clean. Tables } \\ \text { and floors are clean and swept }\end{array} & 0 & 0 & 0 & 0 \\ \begin{array}{l}\text { My classrooms are clean when I come to } \\ \text { school each day }\end{array} & 0 & 0 & 0 & 0 \\ \begin{array}{l}\text { The restrooms in my school are kept clean } \\ \text { n }\end{array} & 0 & 0 & 0 & 0\end{array}$

31. Do you have other comments about school cleanliness? 


\section{School Maintenance}

*32. My school is well maintained.

○ Strongly Disagree

$\circ$ Disagree

- Agree

- Strongly Agree

33. Tell us more about School Maintenance.

\begin{tabular}{|c|c|c|c|c|}
\hline & $\begin{array}{l}\text { Strongly } \\
\text { Disagree }\end{array}$ & Disagree & Agree & Strongly Agree \\
\hline $\begin{array}{l}\text { My school is well-maintained with } \\
\text { working air conditioning and heat }\end{array}$ & 0 & $\mathrm{O}$ & O & O \\
\hline $\begin{array}{l}\text { My school is well-maintained with } \\
\text { working electrical fixtures }\end{array}$ & $\mathrm{O}$ & $\mathrm{O}$ & $\mathrm{O}$ & O \\
\hline $\begin{array}{l}\text { My school is well-maintained with } \\
\text { working restroom fixtures }\end{array}$ & O & O & O & O \\
\hline $\begin{array}{l}\text { My school is well-maintained in } \\
\text { appearance (paint, ceiling tiles, etc.) }\end{array}$ & O & O & O & O \\
\hline $\begin{array}{l}\text { My school is well-maintained with well- } \\
\text { kept grounds }\end{array}$ & O & O & O & O \\
\hline
\end{tabular}

34. Please tell us how we might maintain the school better. 


\section{Bus Service}

* 35. In general, riding the school bus is a pleasant experience.

- Strongly Disagree

○ Disagree

- Agree

- Strongly Agree

- I do not ride the bus

36. Tell us more about the Bus Service.

$\begin{array}{lccccc} & \text { Never } & \text { Rarely } & \text { Sometimes } & \text { Usually } & \text { Always } \\ \text { My bus driver is kind and courteous } & 0 & 0 & 0 & 0 & 0 \\ \begin{array}{l}\text { My school bus is clean and well } \\ \text { maintained }\end{array} & 0 & 0 & 0 & 0 & 0 \\ \begin{array}{l}\text { My bus picks me up on time in the } \\ \text { morning }\end{array} & 0 & 0 & 0 & 0 & 0 \\ \begin{array}{l}\text { My bus gets me home on time after school } \\ \text { M b }\end{array} & 0 & 0 & 0 & 0 & 0\end{array}$

37. Please tell us how we can improve bus service at your school. 


\section{Food \& Nutrition Services}

* 38. I enjoy eating at school.

- Strongly Disagree

$\circ$ Disagree

○ Agree

- Strongly Agree

○ Does Not Apply

39. Tell us more about Food \& Nutrition Services.

Strongly

Disagree

Disagree Agree Strongly Agree

Fresh, high quality food is served at school

o

○

O

○

I get enough to eat at school

O

O

O

O

The cafeteria staff is pleasant and helpful

O

O

○

O

40. How can we improve the food \& nutrition services at your school?

\section{Additional Comments}

41. Is there anything else you would like to tell us about your experience at school? 


\section{APPENDIX B}

Human Subjects Approval

\section{mion \\ OLD \\ DMINION UNIVERSITY}

\section{OFFICE OF THE VICE PRESIDENT FOR RESEARCH}

ARI)

Physical Address

4111 Monarch Way, Suite 203

Norfolk, Virginia 23508

Mailing Address

Office of Research

1 Old Dominion University

Norfolk, Virginia 23529

Phone(757) 683-3460

Fax(757) 683-5902

DATE:

TO:

FROM:

PROJECT TITLE:

REFERENCE \#:

SUBMISSION TYPE: New Project

ACTION:

DECISION DATE:

REVIEW CATEGORY: Exemption category \# 6.4

January 12, 2018

Kosloski Michael, $\mathrm{PhD}$ Programs

January 12, 2018
Old Dominion University Education Human Subjects Review Committee

[1100779-1] Factors Influencing Student Enrollment in Career Academy

DETERMINATION OF EXEMPT STATUS

Thank you for your submission of New Project materials for this project. The Old Dominion University Education Human Subjects Review Committee has determined this project is EXEMPT FROM IRB REVIEW according to federal regulations.

We will retain a copy of this correspondence within our records.

If you have any questions, please contact Jill Stefaniak at (757) 683-6696 or jstefani@odu.edu. Please include your project title and reference number in all correspondence with this committee. 


\section{VITA}

\section{Whitney Stokes Ketchledge 11990 Farrabow Lane Woodbridge, VA 22192 757-646-7604 wstok001@ odu.edu}

\section{$\underline{\text { Academic Degrees }}$}

○ Ed.S. Educational Leadership, Old Dominion University, 2014

○ M.S. Career \& Technical Education, Virginia Polytechnic Institute \& State University, 2011

- B.S. Occupational and Technical Studies, Old Dominion University, 2006

\section{Professional Experience}

- Academy Administrator, Edison High School, Fairfax County Public Schools, Alexandria, VA (July 2017 - Present)

- Director of Career and Technical Education, Hampton City Schools, Hampton, VA (July 2015 - July 2017)

- Career and Technical Education Instructional Leader, Kecoughtan High School, Hampton City Schools, Hampton, VA (July 2011 - June 2015)

- Marketing Teacher, Kecoughtan High School, Hampton City Schools, Hampton, VA (July 2006 - June 2015)

\section{$\underline{\text { Publications }}$}

Ketchledge, W., and Cantu, D. (2013). Using Charlotte's Web as a STEM integrator with social studies. Children's Technology and Engineering, 17(4), p.6.

\section{$\underline{\text { Presentations }}$}

Ketchledge, W. and White, J. (October, 2015). Creating model academies with Ford Next Generation Learning. Presented at the Virginia Association of Career and Technical Education Administrators Conference, Williamsburg, VA.

Ketchledge, W. and White, J. (October, 2015). Getting your CTE message out with video. Presented at the Virginia Association of Career and Technical Education Administrators Conference, Williamsburg, VA. 